الاستفادة من مجلد المقطوعات القصيرة لثيودور كيرشنر

لتحسين أداء الطالب على أله البيانو

أ.د.م. منى عبد الرحيم عادلي احمد

استاذ البيانو المساعد- بكليه التربية النوعية - جامعه جنوب الوادي

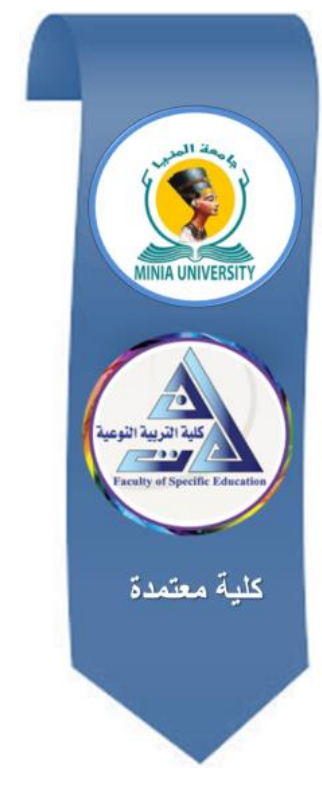

مجلة البحوث في مجالات التربية التوعية

معرف البحث الرقمي DOI: 10.21608/jedu.2021.98772.1483

$$
\text { المجلد الثامن العدد } 40 \text { ـ مايو } 2022
$$

E- ISSN: 2735-3346 P-ISSN: 1687-3424

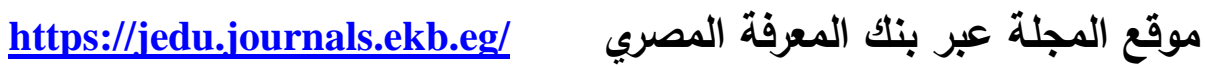
http://jirfse.minia.edu.eg/Hom موقع المجلة

العنوان: كلية التربية النوعية ـ جامعة المنيا ـ جمهورية مصر العربية

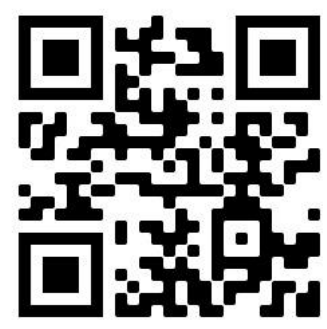


مجلة البحوث فى مجالات التربية النوعية

المجلد الثامن ـ العدد الأربعون ـ مايو 2022 


\section{الاستفادة من مجلد المقطوعات القصيرة لثيودور كيرشنر لتحسين أداء الطالب} على أله البيانو

منى عبد الرحيم عادلي احمد*

\section{المقدمة :}

تعتبر المقطوعات الموسيقية لآلة البيانو من الركائز الأساسية و الهامه

التي يبنى عليها المستوى المهارى للطالب ، حيث أنها تحدد بشكل كبير ما وصل اليه من المهارات العزفيه التي تمكنه من الأداء الجيد وذللك لما تحويه

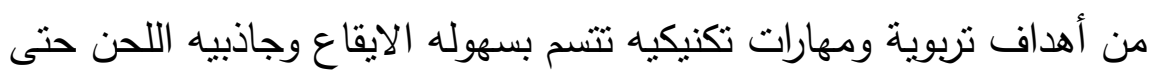

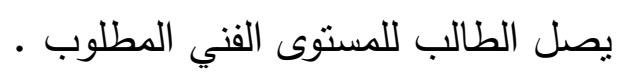
و لقد ارتبطت نهضة الموسيقى في ألمانيا بالبيانو أكثر من ارتباطها بأي ألة

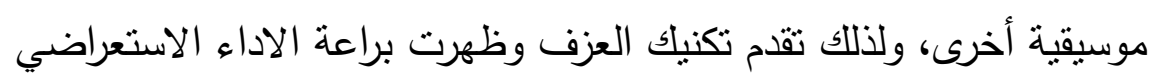

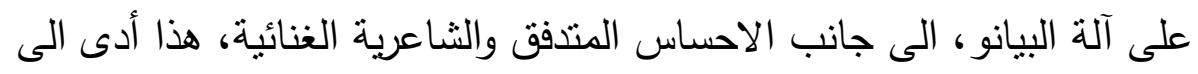

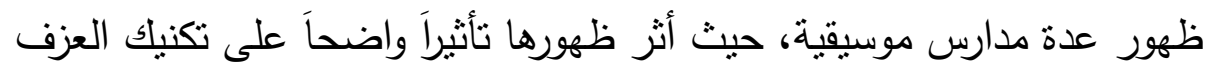

وأسلوب الاداء الموسيقى لكل مؤلف بل وعلى طريقة التأليف نفسها.1 كما ارتبطت الموسيقى الرومانتيكية بالمقطوعات القصيرة، وأصبح

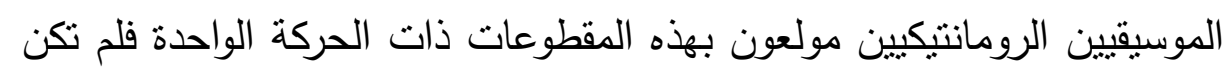
المؤلفات المعقدة تعنيهم بل كان أكثر ما يعنيهم هو كل شيء يتجلى فيه الالهام

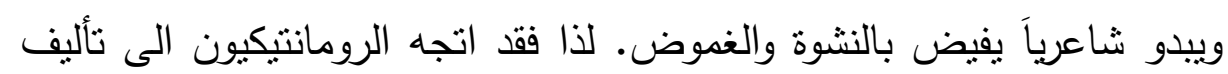

1 Luce, Robert, 1974, p135

* استاذ البيانو المساعد- بكليه التربية النوعبة - جامعه جنوب الو ادي

2 Slonimsky, Nicolas1978, p 262 . 
مقطوعات قصيرة أو مجموعات من المقطوعات القصبرة عرفت فيما بعد بالمنمنمات الموسيقية².

وتزخر ألمانيا بالأسماء الكبيرة في عالم الموسيقى سواء بيتهوفن Ritshard Shtraws أو باخ Bach أو كذلك ريتشارد شتراوس فئوة ، كلها أسماء حفرت اسمها من خلال الألحان من داخل ألمانيا ومنحوا هذا البلد

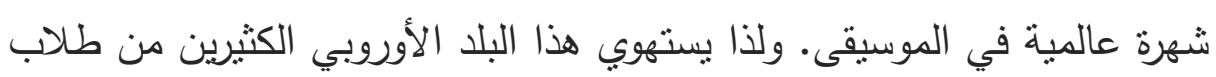
الموسيقى من جميع أنحاء العالم. فمعاهد الموسيقى العليا والجامعات الألمانية تزخر بالألوان الموسيقية المختلف وأنواع الموسيقى التي تلبي جميع الأذواق، ومن هذه المؤلفات المقطوعات القصيرة مصنف 62 للمؤلف الالمانى كيرشنر 3 "Theodor Kirchner"

\section{مشكثة البحث:}

تحظى مؤلفات المقطوعات القصيرة" المنمنمات" بمكانه متميزة من حيث التأليف فهي تمتاز بالبساطة في الالحان والتدرج من السهل الى الصعب وهى ذات حركة واحدة ، تحتوى هذه المؤلفات على مجموعه منتوعة من الاساليب التي أستخدم فيها المؤلف لغة متتاسقة منقدمة تظهر اتقان كيرشنر للشكل المصغر للمقطوعات كل مقطوعة لها شخصية فريدة خاصه بها فيما يتعلق بالهارمونية والمحتوى اللحني والثكل الموسيقى كما تتميز هذه المقطوعات بأسلوب رقصة الفالس و بالتعبير و التوازن بين اليدين عند العزف فهي تعتبر أضافه للمقررات الدراسية وبالرغم من كل هذه المميزات إلا انها لم تحظى بالاهتمام الكافي من الدراسات لذا رأت الباحثة ضرورة تتاولها بالدراسة و التحليل حتى يمكن الاستفادة 
منها لتحسين أداء الطالب على أله البيانو • وتتبع من مشكله البحث التساؤلات

\section{تساؤلات البحث:}

التساؤل الاول : ما المستوى الأدائي لمؤلفات المنمنمات التي تثتاسب

$$
\text { والمستوى التدريسي للمتعلمين؟ }
$$

التساؤل الثانى : ما التقنيات العزفية التي يمكن اكتسابها من خلال التحليل

$$
\text { العزفى لمؤلفات المقطوعات القصيرة عند كيرشنر؟ }
$$

التساؤل الثالث: ما الصعوبات التكنيكية والتعبيرية في مؤلفات المقطوعات

القصيرة عند كيرشنر وما الحلول المقترحة لأدائها ؟

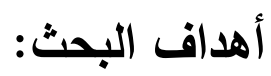

- دراسة مسحيه لمجلد المقطوعات القصيرة مصنف 62 لكيرشنر وتصنيفها

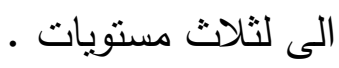

- الاستفادة من التقنيات العزفية لمؤلفات المقطوعات القصيرة" المنمنمات" وتطورها و خصائص أسلوب عزفها عند كيرشنر. - تحديد الصعوبات العزفيه، واقتراح الحلول بالتمارين والإششادات العزفيه لتذليل تلك الصعوبات.

$$
\text { أهمية البحث: }
$$

التعرف على مقطوعات جديدة من شأنها إثراء المناهج الدراسية وتتويعها وايجاد دراسة علمية يمكن الرجوع اليها في حاله الرغبة في عزف مؤلفه المقطوعات

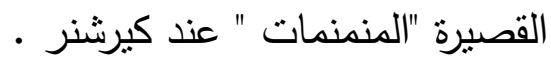

$$
\text { حدود البحث : }
$$

حدود مكانيه : المانيا 


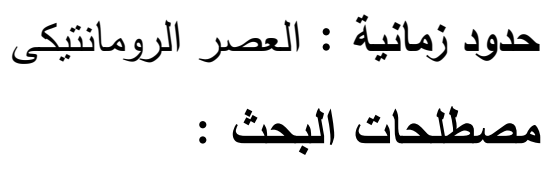

\section{المنمنمات Miniatures}

وتعرف اجرائياً بأنها مقطوعات قصيره تمناز بالبساطة ذات حركة واحدة كل مقطوعة لها شخصية فريدة خاصه بها تتميز باستخدام المسافات الهارمونية المتتوعة ، استخدام الأقواس اللحنية والأقواس الزمنية ، كثرة الانتقال بين بهاه الطبقات الصوتية ، استخدام النغمات الممتدة .

\section{Performance style أسلوب الاداء}

الصفة المميزة للمؤلفة الموسيقية، والتي تعبر تعبيرا واضحا عن الغرض الذى

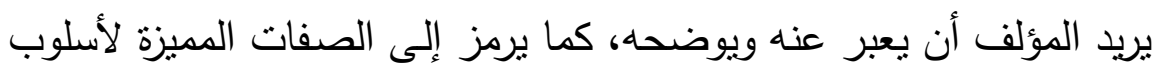
كل مؤلف موسيقى . إجراعات البحث : منهج البحث:

يتبع هذا البحث المنهج الوصفي ( تحليل محتوى ) والذى يقوم على وصف كل ما هو كائن وتفسيره وتحديد الظروف والعلاقات التي توجد بين الوقائع ولا يقتصر هذا المنهج على جمع البيانات وتبوييها وانما يتضمن تفسير هذه البيانات وادراك العلاقة فيما بينها واستخدامها فيما يتتاسب مع مشكلة الدراسة وابعادها.2

Sadie stanly: "The New Grove" .vol 16, U.S.A, Macmillan limited, 1980p.282 ${ }^{1}$ Dicitionary of music and musicans جابر عبد الحميد وأحمد خيرى كاظم : مناهج البحث فى التربية و علم النفس ، دار النهضة العربية ،القاهزة 


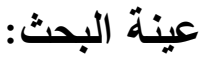

عينه منتقاه من مجلد المقطوعات القصيرة للمؤلف ثيودور كيرشنر لتحسين أداء الطالب على أله البيانو ونم انتقاء العينة من مستوبين المتوسط وفوق المتوسط و ذللك بعد عمل مسح شامل للمؤلفات وتصنيفها الى ثلاث مستويات ملحق (1) وعمل استمارة استطلاع رأى الساده الخبراء المتخصصين في تصنيف المؤلفات ملحق (2) وعمل استمارة استطلاع رأى الساده الخبراء المتخصصين في رائ

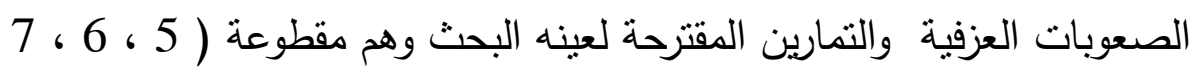
، 8 ) وذلك لملائمتهم للمستوى الاكثر شيوعا بالنسبة للطلاب .

$$
\text { أدوات البحث: }
$$

المدونات الموسيقية_ آلة البيانو_ المراجع_ مصادر الانترنت_- استمارة استطلاع راي الخبراء في الصعوبات العزفية والتمارين المقترحة - استمارة استطلاع راي الخبراء فى التحليل العزفى و تحديد المستوى التذريسي

$$
\text { خطوات البحث }
$$

الجزء الأول: الجانب النظري و يشمل:

دراسات سابقة مرتبطة بموضوع البحث - نبذة عن حياة المؤلف ثيودوركيرشنر "Theodor Kirchner" أهم أعماله - سمات مؤلفات المقطوعات القصيرة المنمنمات مصنف 62

الجزء الثاني: الجانب التطبيقي ويشمل تحليل العناصر الموسيقية( السلمالميزان- الطول البنائى- الصيغة- السرعة- الافكار اللحنية- التعبير ووسائل التظليل- الحليات- البيدال) ودراسة تحليلية عزفية لاربع منمنمات للبيانو. واستخراج الصعوبات التكنيكية وتذليلها عن طريق التمارين المقترحة والإششادات 


\section{دراسات سابقة:}

اولا: دراسات عربية:

الاراسة الاولى : دراسة شرين سمير محمود الجندي بعنوان :

" استخدام التقتيات الموسعة لالة البيانو في أداء منمنمات البيانو في

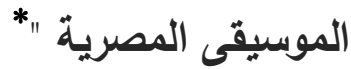

هدفت تلاك الدراسة الى: القاء الضوء علي مؤلفات المنمنمات عند المؤلفة المصرية نهله مطر واختارت منها الباحثة عملا بعنوان " ثمان منمنمات مصريه للبيانو" تتاولت فيها المؤلفة التقنيات الموسعة لالة البيانو واعتمدت الدراسة علي ليان

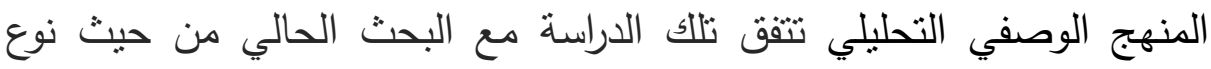
المؤلفة والمنهج، تختلف مع البحث الحالي من حيث استخدام التقنيات الموسعة لالة البيانو واستخدامها فى الموسيقى المصرية أما البحث الحالي فيقوم بدراسة المقطوعات القصيرة أو المنمنمات عند المؤلف الألماني كيرشنر من حيث البران

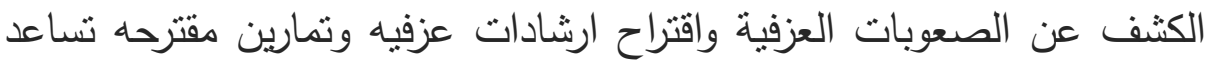
الطالب على سهوله أداء تلك المؤلفات واختيار منها ما يناسب الطالب لإسراء المناهج الدراسية بمؤلفات جديدة مختلفة وغير تقليدية .

\section{الاراسة الثانية : دراسة آية يوسف محمد محمد بعنوان :}

طريقة مقترحة لمعالجة الصعويات العزفية من خلال مجلد دنيس آجاى

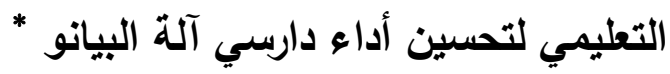

* شرين سمير محمود الجندي: بحث انتاج المؤتمر الدولي الاول (العلمي الثامن) كليه التربية الموسيقية جامعه حلوان 2010. * آية يوسف محمد محمد : رساله ماجستير غير منشورة - كليه التربية النوعية ـ جامعة عين شمس 2010 
هدفت تللك الدراسة الى التعرف على أسلوب دينيس أجاى من خلال مؤلفاته لتعليم عزف آلة البيانو للمبتدئين و تحديد الصعوبات العزفية وتقديم التدريبات والإرشادات لمعالجة ما به من صعوبات والاستفادة من المؤلفات عينه البحث في تحسين أداء دارسي أله البيانو تكمن أهمية هذه الدراسة فى الاستفادة من الدراسة التحليلية العزفية للمؤلفات عينة البحث في تتميه المهارات للطالب على البى البه أله البيانو واعتمدت الدراسة علي المنهج الوصفي التحليلي وتتاولت عينه البحث عينة مختارة من مجلد دينيس أجاى تحتوى على12 مقطوعة اختارت الباحثة 4 مقطوعات تتفق تلك الدراسة مع البحث الحالي فى تحسين أداء دارسي آلة دئل البيانو والمنهج، تختلف مع البحث الحالي من حيث الطريقة المقترحة لمعالجة الصعوبات العزفية من خلال مجلد دنيس آجاى التعليمي لتحسين أداء دارسي آلة البيانو أما البحث الحالي فيقوم بدراسة المقطوعات القصيرة أو المنمنمات عند المؤلف الألماني كيرشنر من حيث الكثف عن الصعوبات العزفية واقتراح ارشادات عزفيه وتمارين مقترحه تساعد الطالب على سهوله أداء تلك المؤلفات واختيار منها ما يناسب الطالب لإسراء المناهج الدراسية بمؤلفات جديدة مختلفة وغير تقليدية

الاراسة الثالثة: دراسة مروة عاطف سلامه عبد الرحمن بعنوان

دراسة تحليلية عزفية لمقطوعات المجلد الأول لسوليما سترافنسكي لتنمية

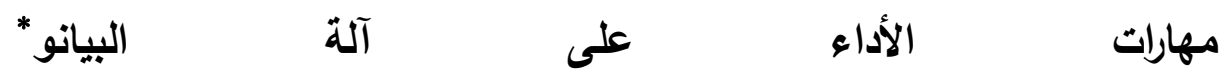
هدفت تلك الدراسة الى التعرف على خصائص العناصر الموسيقية التى تتسم بها مقطوعات المجلد الأول لسوليما سترافنسكى لموسيقي البيانو للأطفال "

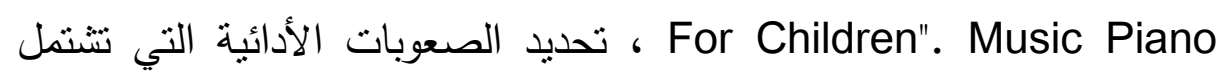
* مروة عاطف سلامة عبدالرحمن : بحث منشور مجلة بحوث في التربية النوعية ـ العدد الثاني- جامعة المنبا 
عليها عينه البحث من خلال التحليل البنائي والتحليل العزفى ، ترجع أهمية البحث إلى تفهم الخصائص الفنية التي تتسم بها عينه البحث وهذا بساعد على تحسين أداء العازف المبتدئ وقد أتبع هذا البحث المنهج الوصفي التجريبي ذو المجموعة التجريبية الواحدة ، المنهج الوصفي (تحليل محتوى ) تتفق تلكك الدراسة مع البحث الحالي فى تحسين أداء دارسي آلة البيانو ، تختلف مع الته ، البحث الحالي من حيث نوع المجلد والمؤلف أما البحث الحالي فيقوم بدراسة المقطوعات القصيرة أو المنمنمات عند المؤلف الألماني كيرشنر من حيث الكثف عن الصعوبات العزفية واقتراح ارشادات عزفيه وتمارين مقترحه تشاعد الطالب على سهوله أداء تللك المؤلفات واختيار منها ما يناسب الطالب لإسراء المناهج الدراسية بمؤلفات جديدة مختلفة وغير تقليدية .

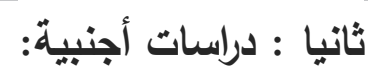

\section{THEODOR KIRCHNER'S : MINIATURES, OP62 A}

\section{PEDAGOGICAL ANALYSIS ${ }^{*}$}

هدفت تللك الدراسة الى تتاول مؤلفه المنمنمات تربويا للوقوف على ما يناسب

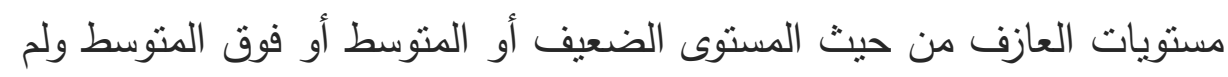
يتطرق الباحث الى الصعوبات العزفيه ولا عمل إرشادات عزفية أو تمارين مقترحة كما فعلت الباحثة فى عينه البحث وهم عدد (4) مقطوعات كنموذج

${ }^{*}$ CANDACE FISH :THEODOR KIRCHNER'S MINIATURES ،OP 62 A PEDAGOGICAL ANALYSIS, Norman, Oklahoma. 2020

التحليل التربوى لمؤلفة المنمنمات مصنف 62 عند ثيودور كيرشنر

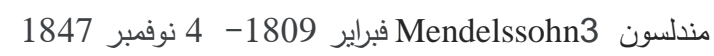


لأسلوب أداء كريشنر لهذه المؤلفات ولقد استتتب الباحثة من خلال عزف

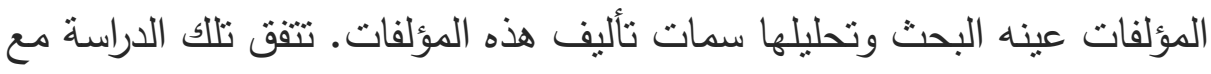
البحث الحالي من حيث نوع المؤلفة والمنهج ، تختلف مع البحث الحالي من حيث الكثف عن الصعوبات العزفية واقتراح ارشادات عزفيه وتمارين مقترحه تساعد الطالب على سهوله أداء تلك المؤلفات واختيار منها ما يناسب الطالب لإسراء المناهج الدراسية بمؤلفات جديدة مختلفة وغير تقليدية .

\section{نبذة عن حياة المؤلف كيرشنر:}

ولد ثيودور كيرشنر بالمانيا عام 1823 وكان مؤلفًا موسيقيًا وعازف بيانو وعازف أرغن تلقى دروسًّه في العزف على البيانو و بعد الانتهاء من دراسته التحق بمعهد لاييزيغ leipzig الموسيقي في عام 1843 ، بناءً على توصية من مندلسون Mendelssohn ذهب إلى سويسرا حيث تولى منصب عازف الأرغن في الكنيسة المحلية. في نفس الوقت قدم حفلات موسيقية وعمل كمدرس للموسيقى

- في عام 1862 عمل كقائد في لاييزيغ حيث قاد حفلات (AMG) وهنا تعرف على يوهانس برامز Brahms ، الذي أصبح صديقًا لله مدى الحياة. - عام 1868 تزوج من المغنية ماريا شميدت Maria Schmidt في زيورخ و نتج عن هذا الزواج ثلاثة أطفال. - عام 1872 غادر سويسرا وعاد إلى ألمانيا حيث عمل مدرسًا للموسيقى، وبعد عام واحد شغل منصب مدير مدرسة الموسيقى المحلية. - عام 1876 عمل لبضع سنوات كمدس موسيقى في لاييزيغ. - عام 1883 انتقل إلى معهد دريسدن Dresden Institute الموسيقى • 
- عام 1890 ذهب كيرشنر إلى هامبورغ ، حيث أصبح شبه أعمى -

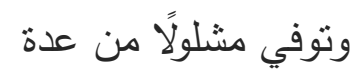

وكان كيرشنر غزير الإنتاج ومع ذللك لا يزال غير معروف لدى العديد من عازفي البيانو اليوم .كان لدى كيرشنر علاقات وثثقة مع العديد من الملحنين المشهورين و يتكون إنتاجه الموسيقي في الغالب من منمنمات البيانو ، والتي يبلغ مجموعها 73 و كمؤلف تجنب الأشكال الكبيرة وقدم أفضل ما لديه من إنه القطع التعبيرية و تتألف أعمال البيانو وحدها من أكثر من 1000 مقطوعة

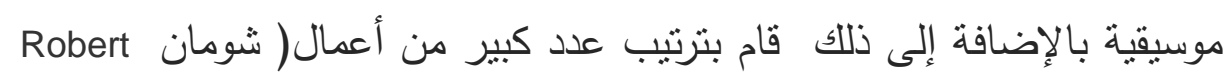
) و (برامز Schumann البيانو الرومانسية.

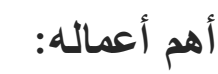
مؤلقات للبيانو: - خمس قطع بيانو (مصنف 5)، تسع قطع بيانو (مصنف 7)، شيرزو (مصنف 8)، اسكتشات، قطع البيانو الصغيرة (مصنف 11)، 7 قطع بيانو ( مصنف 13) بعنوان أغاني بدون كلمات. -تشع قطع فانتازيا (مصنف 14)، اثثا عشر قطعة بيانو (مصنف 16) بعنوان ألعاب المرح والمآسي الصغيرة

https://ar.wikipedia.org/wiki

شومان Robert Schumann: 8 يونيو 1810 -29 يوليو 1853 - 1856 برامز Brahms : مايو 1833 - 3 أبريل 1897 : 189 
-عشر مقطوعات بيانو مبنية على أغانيه الخاصة( مصنف 19)، 12 قطعة بيانو(مصنف 21) بعنوان ألوان مائية ، ثمانية رومانسيات( مصنف 22)، اثثا عشر فالس (مصنف 23)

- 8 قطع بيانو (مصنف 24 ) بعنوان لا يزال يتحرك ، 10 قطع (مصنف (بعنوان صور ليلية. - 12ألبوم للبيانو عبارة عن قطع صغيرة (مصنف 26)،4 قطع للبيانو (مصنف 28) بعنوان، 6 قطع موسيقى هادئة (مصنف 29) بعنوان من كراسة الرسم

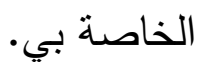

- 10 قطع (مصنف 32 ) بعنوان من الأيام الكئية ، 5 قطع بيانو (مصنف 33 ) بعنوان المثل. -7 رقصات فالس( مصنف 34) ،14 قطعة بيانو سهلة (مصنف 35 ) بعنوان

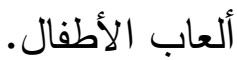
- التخيلات على البيانو (مصنف 36) ، 14 قطعة بيانو (مصنف 39) بعنوان قصص القرية. - 6 قطع بيانو (مصنف 41) بعنوان الأوراق المنفوخة ، 7 مازوركا مصنف

-10 قطع بيانو ( مصنف 44) بعنوان زهور للباقة ، 6 قطع بيانو (مصنف

-12 من مؤلفات البيانو بأربع أيدى (مصنف 57)، 6 قطع أحرف (مصنف

-15 قطعة سهلة (مصنف 62) بعنوان المنمنمات. - 30 دراسة صغيرة للبيانو تستتد إلى الأغاني الثعبية القديمة وأغاني الأطفال (مصنف 66) بعنوان أعزائي الشباب، 5 سوناتينات(مصنف 70). 
مؤلفاته لموسيقى الحجرة: - أغنية Serenade للبيانو والكمان (مصنف 15)، ثناثيات أطفال للبيانو والكمان (مصنف 58)، روايات للبيانو والكمان (مصنف 59)، أغنية

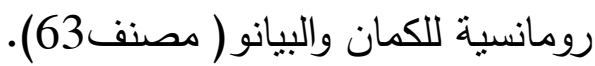
- ثماني قطع للفيولا (أو الفيولا ، الكمان) والبيانو (مصنف ولنه)، أوراق ملونة للبيانو والكمان (مصنف 83)، اثنا عشر قطعة خيالية للكمان والبيانو

$$
\text { (مصنف 90). }
$$

الأغاني:

-10 أغاني (مصنف 1) ،أغاني البنات (مصنف 3) ،4 أغنيات (مصنف 4) - بالاد (مصنف 10) ، 3 أغانٍ بناءً على نصوص(FvHolstein مصنف -

- أغنية الصحوة في الحب (مصنف 67) ، أغنية بالقرب من الحبيب (مصنف 168 - أغنية أتجول في الليلة الصامتة ( مصنف 95) ، بالاد هنري الرابع في باحة كانوسا (مصنف 102) الكورال - 2013 أربع قصائد لجوقة الذكور (مصنف 69 ) طبعة برلين - الأغاني الشعبية ( مصنف 93) ، مقطوعتان للكمان والأرغن (مصنف 92) 1 https://www.wikiwand.com/de/Theodor_Kirchner1 


\section{الجزء الثاني: الجاتب التطبيقي:}

ترى الباحثة أن مؤلفه المقطوعات القصيرة "المنمنمات Miniatures "عند المؤلف كيرشنر تحتوى على العديد من التقنيات العزفية مثل البساطة في الالحان والتدرج من السهل الى الصعب والكثير من التقنيات التي تستحق الدراسة وقد قامت الباحثة بعمل دراسة مسحيه بتحليل مؤلفات المقطوعات القصيرة "'المنمنمات Miniatures عند المؤلف كيرشنر وعددهم (15) منمنمه تحليلا بنائيا للتعرف على ما يتتاسب مع الطلاب من حيث المستوى التدريسي ملحق (1)، ثم التحليل العزفى لعدد(4) منمنمات (5،6،78، )لمالائمتها لمعظم المستويات بالنسبة للطالب و كعينه للتعرف على الصعوبات العزفية وكيفية أدائها والتغلب عليها عن طريق الارشادات العزفية والتمارين المقترحة . مقطوعه ( 5 )

أولا: التحليل البنائي FORM Analysis الميزلن / السلم: دو / الكبير الطول البنائي: 47مازورة

A | B | Coda : الصيغة النسيج : ايموفوني مصطلحات السرعة: ziemlich langsam, ausdrucksvoll ببطيء مع قليل

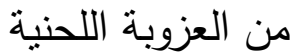
spress rall : وهو اختصسار لمصطلح Rallentando و يعنى أبطاء تدريجي للحركة. 
| dolce A tempo

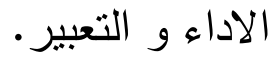

: Sotto :Sempre dim الاستمرار الدائم فى الاداء من القوة الى الخفوت:

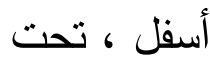
التظليل ومصطلحات التعبير:

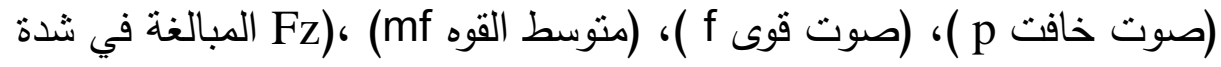

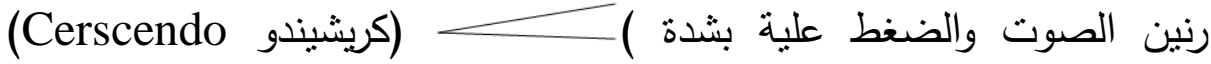
يعنى التدرج من الخفوت الى القوة،(ديمينوندو (Diminuendo) ويعنى التنرج من القوة الى الخفوت، (.) Staccato عزف منقطع ويؤدى بخفة ويعادل ربع القيمة الزمنية للعلامة ، Rit-tempo يعنى التنرج في البطء ثلثم العودة للسرعة الأصلية. الحليات : استخدم المؤلف حلية الاربيجيو كما أستخدم المؤلف حلية الاتشاكاتورا (Acciaccatura) وهى نوع من الحلية الزخرفية اللحنية تكتب على هيئة

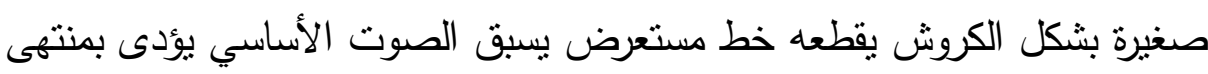

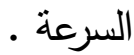

البيدال: استخدم المؤلف البيدال بمناطق لحنية لإظهار اللحن. تحليل الأداء Performance Analysis

اللحن والتقتيات الأدائية: تتطلب هذه المؤلفة العزف البطيء مع قليل من

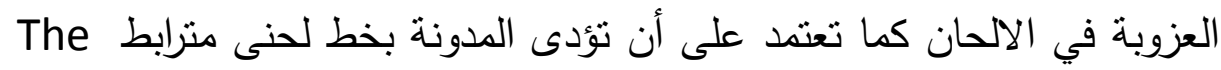
Melodic line

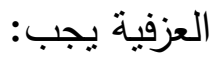


التحكم فى كمية وكيفية اخراج الصوت الموسيقى وارتباطه بالأصوات التي تسبقه والتي تليه لذا يجب الاهنمام بالزمن الخاص باللحن ككل وليس الاهتمام بالضغط القوى على بداية كل مازورة حتى لا تفقد الجملة انسيابها الجزء A: يبدأ من م (1: 30 ) كما بالثكل التالى:

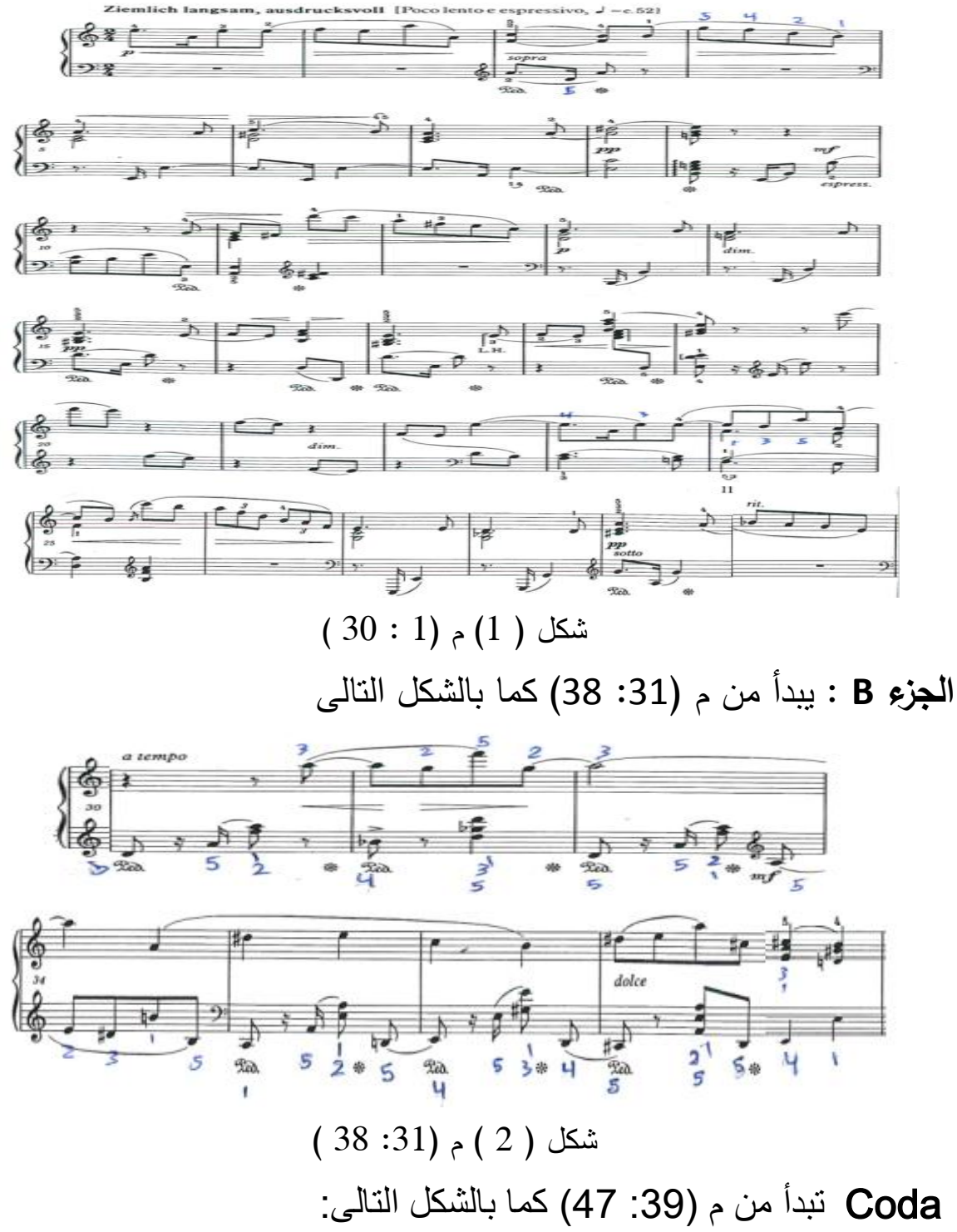




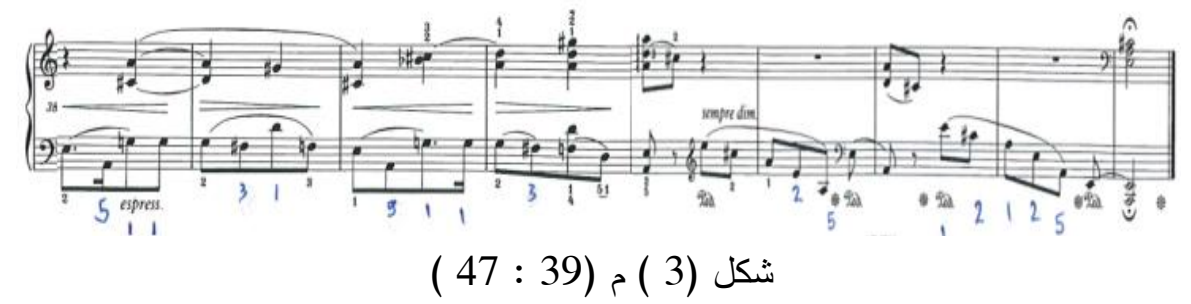

الجزء A : يحتوى هذا الجزء على عدة تقنيات عزفية لابد من التدريب عليها

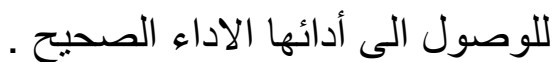

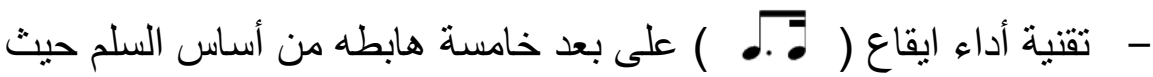

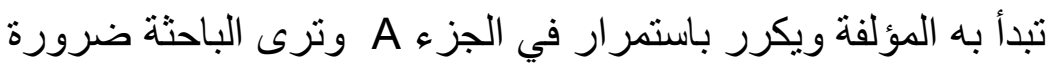

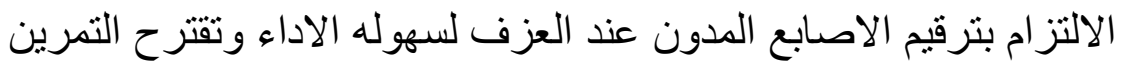
التالي لسهولة الاداء.

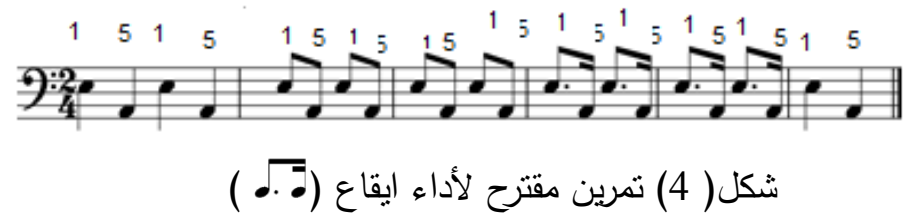

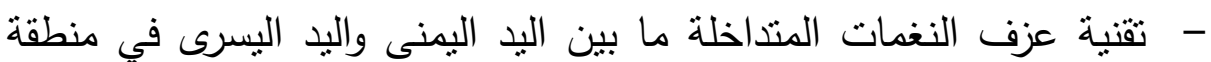
واحدة م (3 ) وهى المنطقة الوسطى لوجود مفتاحي صول مما يشكل عبأ على العازف في التركيز على عزف كلتا اليدين بإيقاعات مختلفة في وقت واحد لذا ترى الباحثة ضرورة التدريب لكل يد على حدى حتى تمام الاتقان

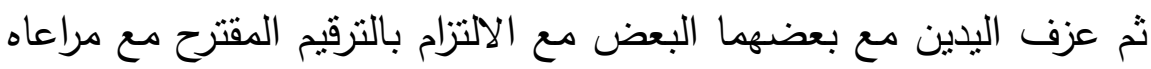
الاقواس اللحنية لكلتا اليدين كما بالثكل التالى :

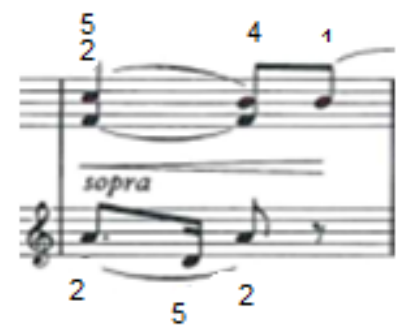

شكل( 5) ترقيم مقترح لمازورة (3) 
- تقنية عزف حليه الاربيجيو م (9) على أيقاع الكروش وتكمن الصعوبة فى أداء الحلية في نفس زمن الايقاع لذا يجب مراعاة عزف نغمات الحلية بقوة واحدة وببطء ولابد ان تأتى حركة الاربيجيو بتغيير مركز نقل الذراع من

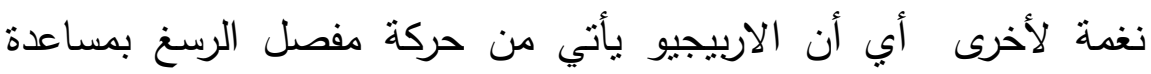

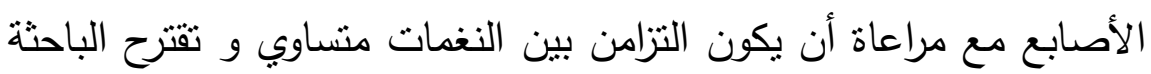
العزف ببطيء لضبط زمن الايقاع كما توضح الباحثة تمرين مفترح لكيفية

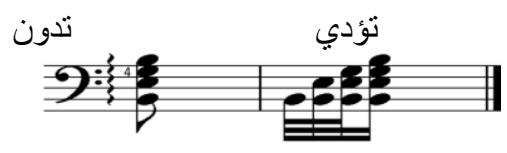
كيفيه تدوين حليه الارجبيو

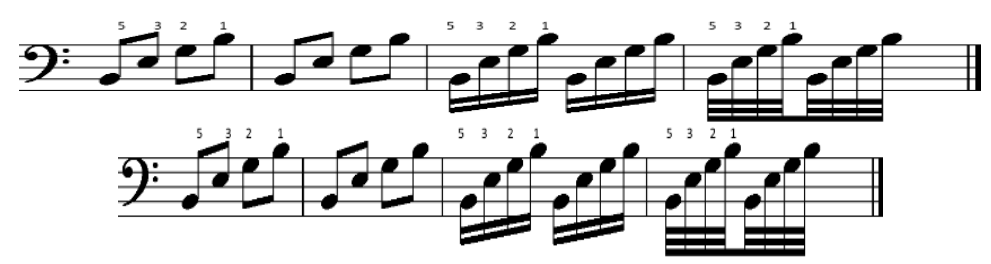
شكل (6 ) تمرين لأداء حلية الأربيجيو

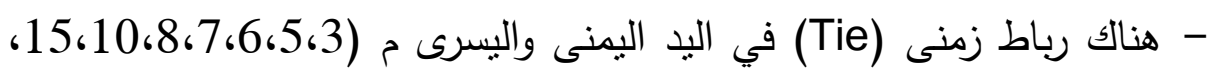
24،23) ويعنى الاستمرار في عزف النغمة حتى انتهاء زمنها كاملا . - م (18،17) مراعاه أداء النغمات باليد اليسرى فى مفتاح صول لوجود لورد

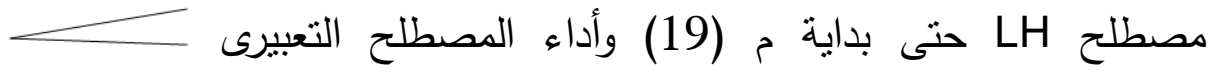
(كريشيندو Cerscendo) يعنى التدرج من الخفوت الى القوة، (ديمينوندو (Diminuendo مدى التجانس العزفى بين اليدين م (19). 
م (29) يراعى الاداء أوكتاف لأسفل لوجود مصطلح Sotto مع مراعاه أداء pp المصطلح التعبيري

\section{الجزء B ( )}

-يديدأ من م (31: 38) و يعتمد على التتقلات اللحنية السريعة فى اليد اليسرى

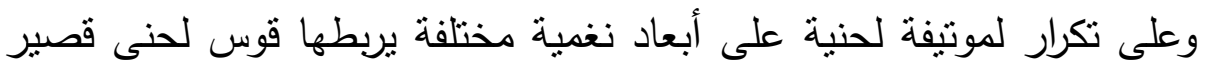

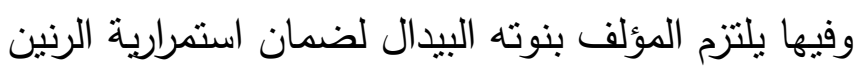

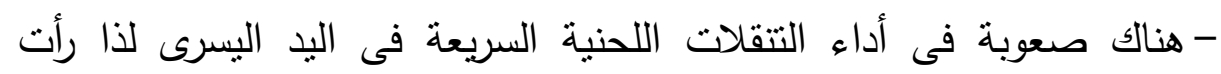
الباحثة الاداء بترقيم الاصابع المقترح من الباحثة لسهولة الاداء كما بالثكل

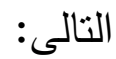
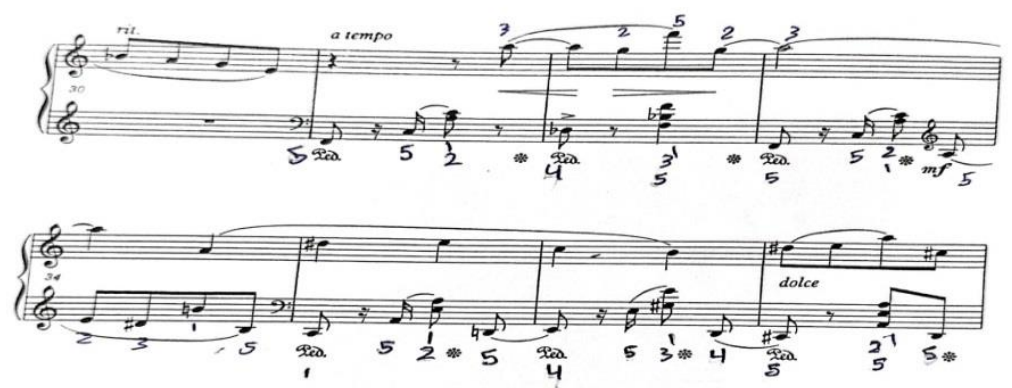

شكل( 7 ) م (31: 38 ) بترقيم الاصابع المقترح

Coda

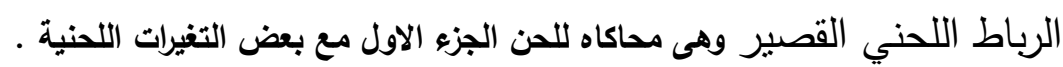

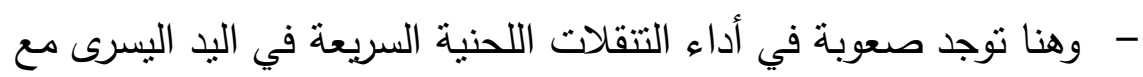
وجود الرباط اللحني لكل مازورة على حدى مع ضبط المصطلح التعبيرى

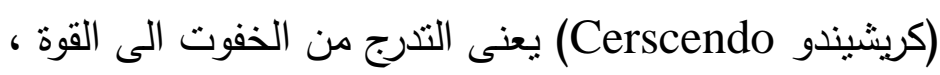

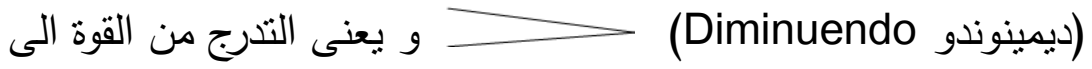
الخفوت ليوضح مدى التجانس العزفى بين اليدين. 
- - لذا رأت الباحثة الاداء بترقيم الاصابع المقترح من الباحثة لسهولة الاداء كما بالثكل التالي
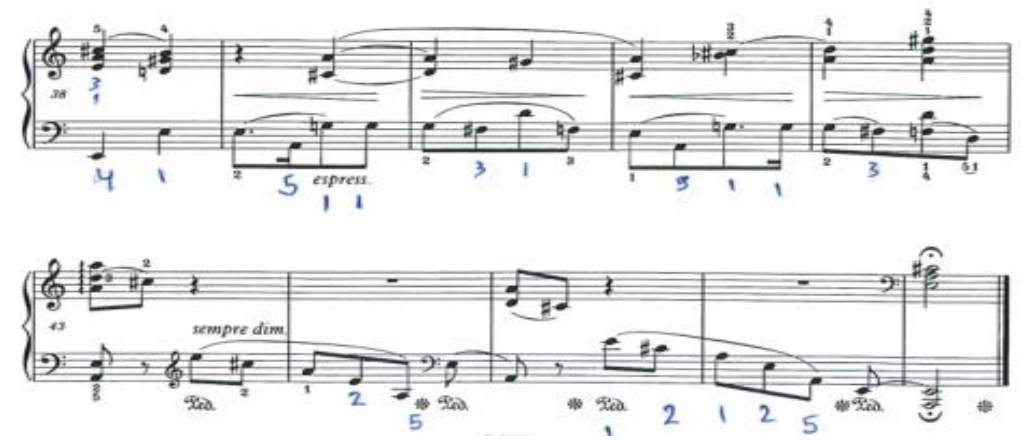

شكل( 8 ) بترقيم الاصابع المقترح

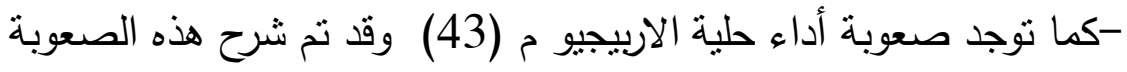
سابقا بنفس المؤلفة.

-قد أختتم المؤلفة في مفتاحي (فا) لكلا اليدين بتألف ثناثي على الدرجة الاولى لسلم الاساس مع استخدام علامه ( (م) وتعنى الاطالة في الزمن. - - - تقتيه تغير المفاتيح الموسيقية حيث ينتوع أداء المؤلف فى استخدام الطبقات الصوتية المختلفة وهى السمة السائدة على المؤلفة. -وتقترح الباحثة للتدريب هذه التقنية بوضع علامات بالقلم الرصاص علي المفاتيح المتغيرة حتى تلاحظها العين عند العزف.

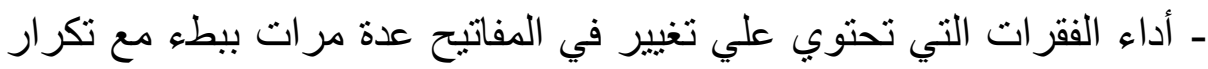
العزف حتى يتعود العازف على ادائها بسهوله ويسر . تعليق الباحثة : ترى الباحثة أن هذا العمل من أكثر الاعمال التي تساعد على لهي

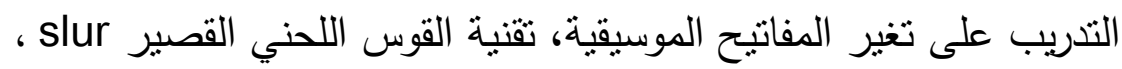
والتدريب على تغيير المفاتيح في اليد اليسرى، كما تساعد الطالب على استخدام

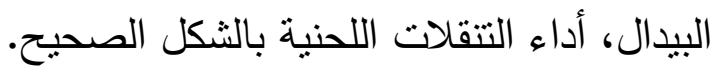




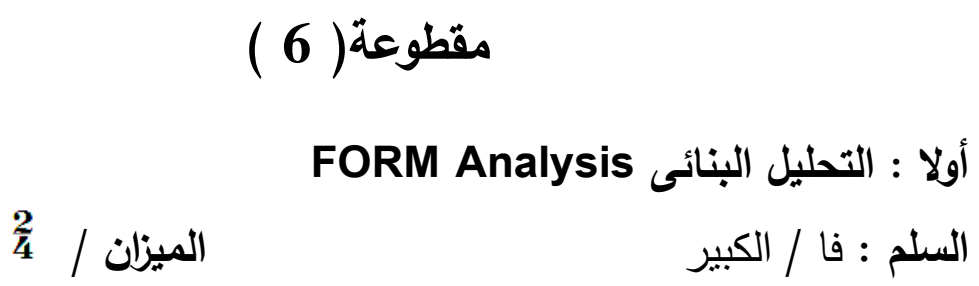

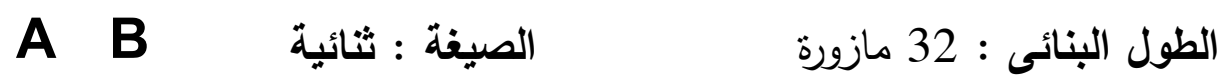

النسيج : هيموفوني

أسلوب الاداء : Vivace ويشير هذا اللفظ للحركة السريعة جدا النشطة الاكثر

حيوية من Allegro

التظليل ومصطلحات التعبير:

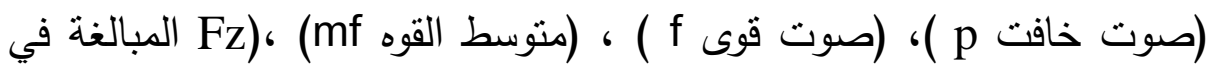

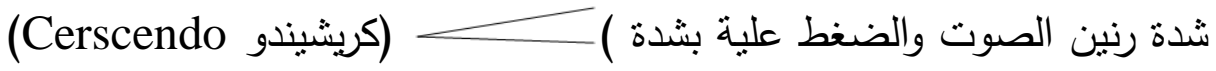

يعنى التدرج من الخفوت الى القوة، (ديمينوندو لهiminuendo) ويعنى التدرج من القوة الى الخفوت ، (. Staccato عزف متقطع ويؤدى بخفة ويعادل ربع القيمة الزمنية للعلامة ، Rit-tempo يعنى التدرج في البطء ثم العودة للسرعة الأصلية.

الحليات : أستخدم المؤلف حلية الانتشاكاتورا(Acciaccatura) وهى نوع من الحلية الزخرفية اللحنية تكتب على هيئة صغيرة بشكل الكروش يقطعه خط مستعرض يسبق الصوت الأساسي يؤدى بمنتهى السرعة.

البيدال: لم يستخدم المؤلف البيدال

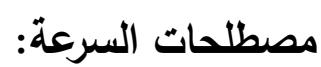

A tempo 
rfz : وهو اختصار لمصطلح Rinforzando و تعنى الاداء برنين أكثر وتشديد النبر على نغمة دون باقي النغمات.

\section{تحليل الأداء Performance Analysis :}

اللحسن والتقتيات الأدائية: تتميز هذه المؤلفة بالمرح والغنائية والاداء المعبر وتتكون من جزئيين تمناز بالرشاقة و الانسيابية مع استخدام الإيقاعات البسيطة

\section{(الجزي}

يبدأ من م (1 : م 8) وتتنهى بققله تامه سلم فا / ك اللحن مبني على استخدام النغمات الأساسية لتآلف الدرجة الخامسة لسلم الاساس وتتابع النغمات السلمية

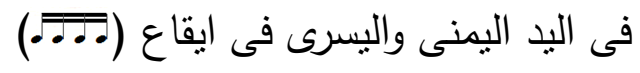
في أداء متبادل بين اليد اليمنى و اليد اليسرى مع استخدام القوس اللحني القصير slur ، استخدام حلية الاتتيكاتورا على ايقاع (مُ )، . كما بالثكل التالي:
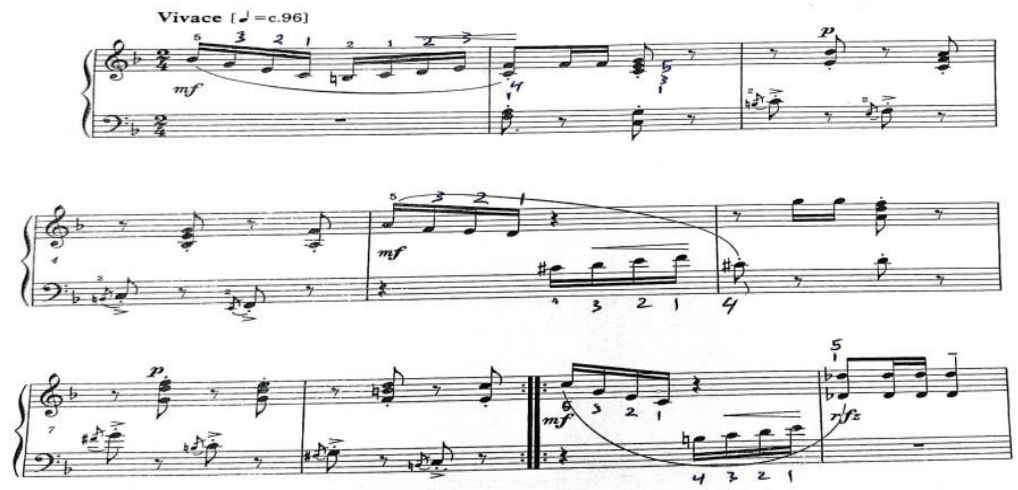

$$
\text { شكل(9 ) الجزء الاول م (1 : } 8 \text { ) }
$$




\section{الجزء الثانى B (الجى}

يبدأ من م (9: 16) ينتهى بققلة تامة سلم فا/ ك وهى عبارة عن تالفات مفردة فى اليد اليمنى ونغمات سلمية فى اليد اليسرى تعزف في تبادل عزفى ما بين اليد اليمنى و اليد اليسرى و نغمات مزدوجة وأوكتافات

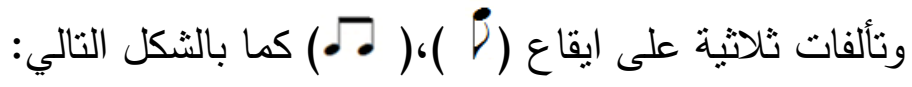
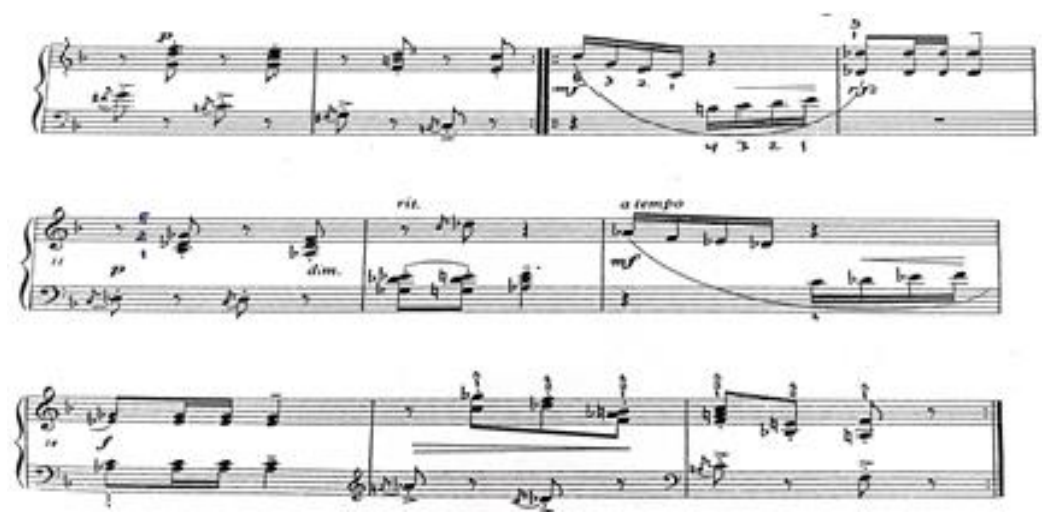

$$
\text { شكل (10 ) الجزء الثاني م (9: } 16 \text { ) }
$$

الارشادات العزفية و التمارين المقترحة :

- تقنية أداء القوس القصير slur مثال م(13،19، 19، يتطلب أداء القوس القصير slur الضغط بتقل من الذراع عند بدء عزف القوس اللحني ثم

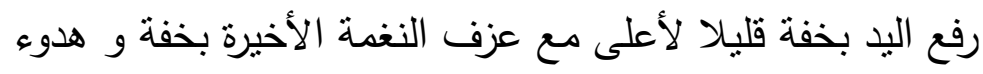

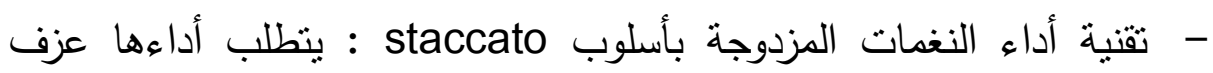
الأصابع بحركة من اليد والساعد كوحدة واحدة و في زمن منساوي مع عدم رفع الأصابع عن النغمات قبل الركوز على النغمات التي تليها و الاستدارة الكاملة للأصابع حتى تتساوى قوة عزف الابع عن النغمات. - تقنية أداء مصطلح Marcato لأداء المتقطع الثقيل tenuto (-) وهما بنفس المعنى ونفس الاداء مثال م (14،10 ) م (10) في شكل اوكتاف، م 
(14) نغمات مزدوجة ويثير هذا المصطلح للالتزام بإعطاء النغمة مدتها الزمنية كامله كما تعنى الاداء بعمق ووضوح و هي عبارة عن شرطة قصيرة تكتب أعلى أو أسفل النغمة. - تقنية أداء علامة الضغط القوى(>) م (16،867،3) وكتبت على حلية

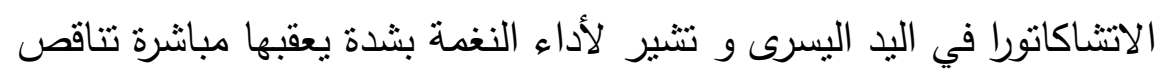
تدريجي و عند نكرار العلامة أكثر من مرة في المأزورة الواحدة تعنى تشديد

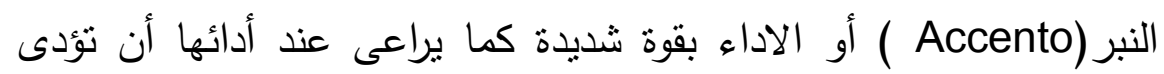

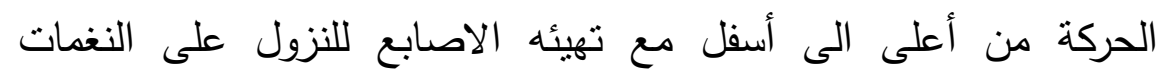

$$
\text { الصحيحة. }
$$

- تقنية أداء التألف الثلاثي مثال م (2 ، ويتطلب أداء التألف الثناثي التدريب على أداء نغمات التألف مفردة ثم أدائها

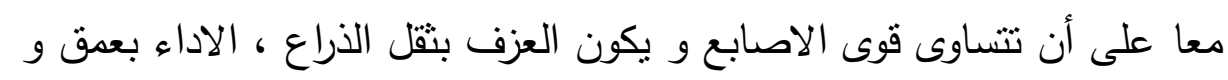
تقترح الباحثة التمرين التالي لسهوله الاداء.

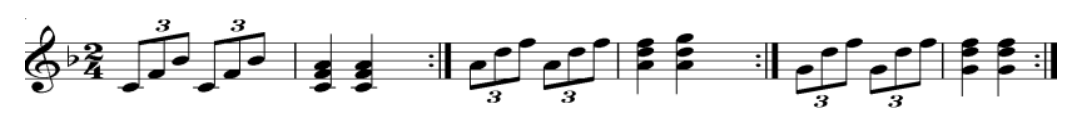

$$
\text { شكل ( 11) تمرين مقترح لسهوله أداء الثآلف الثناثي }
$$

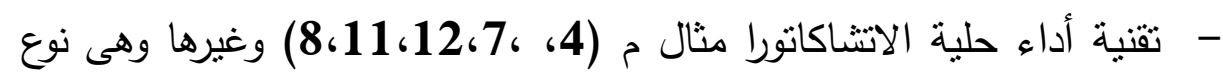
من الحلية الزخرفية اللحنية تكتب على هيئة صغيرة بشكل الكروش يقطعه خط مستعرض يسبق الصوت الأساسي وتؤدى كما بالثكل التالي. تؤدي

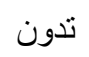$$
\text { تؤدي }
$$
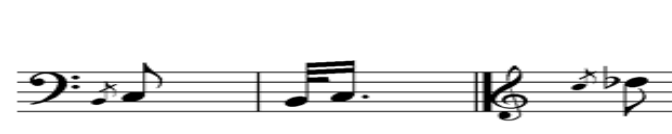

شكل (12) كيفية أداء حلية الاتثاكاتورا 


\section{الارشادات العزفية}

- مراعاه أستخدم التلوين التعبيري rit و تعنى بطء تدريجي ثم العودة مرة

أخرى الى الزمن الأصلي بوضع علامة a tempo كما هو موضح م (13،12).

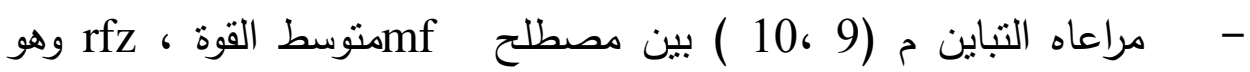
اختصار لمصطلح Rinforzando و تعنى الاداء برنين أكثر وتتثديد النبر على مهن مهن نغمة دون باقي النغمات الاخرى.

- - مناك صعوبة في أداء نغمات اليد اليمنى في تتابع لاختلاف الابعاد النغمية. بأسلوب stacato وخصوصا مع الاداء المتبادل بين اليدين مع استخدام الحلية فى اليد اليسرى (16،15) وللتغلب على هذه الصعوبة يجب الاداء بالترقيم المقترح من الباحثة لسهوله الاداء. - مراعاه الاداء المترابط legato م (14:13،2:10:9، 14:13) مع مراعاه الاداء فى تتابع على أن تكون اليدين قريبه جدا من بعضها البعض لتبدو كما لو كانت يد واحدة التي تقوم بالأداء.

تعليق الباحثة : ترى الباحثة أن هذا العمل من أكثر الاعمال التي لي لئ تساعد على التدريب على الاداء المتبادل بين اليد اليمنى و اليد اليسرى ،

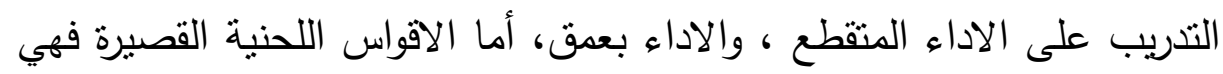
تبرز النغمات المزدوجة في أخرها بالإضافة الى استخدام التظليل mf في بداية التهاء القوس اللحني مما يجعل الهدف التعبيري في خدمة الهدف التكنيكي.

\section{مقطوعة ( 7 )}
FORM Analysis أولا : التحليل البنائى
3 الميزان /
السلم : دو / الكبير
A الصيغة : أحاديه
الطول البنائي : 32 مازورة 
Nicht zu : أسلوب الاداء

$$
\text { النسيج : هيموفوني }
$$

سريع مفعم بالحيوية:Sch nell

التظليل ومصطلحات التعبيز :

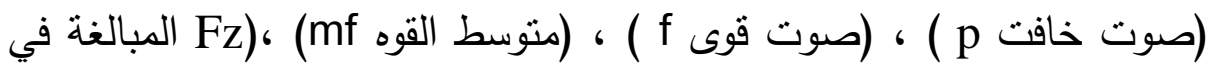

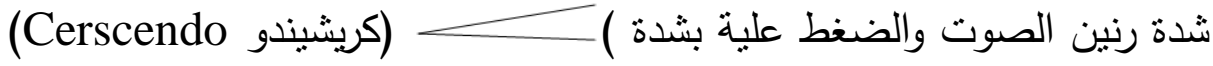
يعنى التذرج من الخفوت الى القوة، (ديمينوندو لهiminuendo) ويعنى التدرج من القوة الى الخفوت، (.) Staccato عزف متقطع ويؤدى بخفة ويعادل ربع القيمة الزمنية للعلامة ، Rit-tempo يعنى التدرج في البطء ثم العودة للسرعة الأصلية. البيدال: أستخدم المؤلف البيدال بكثرة لأثراء اللحن وحتى يتمكن العازف من الانتقال بين النغمات بانسيابيه. A poco rit : تعنى بقليل من التدرج من القوه الى الخفوت tempo

\section{- تحليل الأداء Performance Analysis -}

اللحـن والتقتيات الأدائية: تتطلب هذه المؤلفة من العازف التتقل على نطاق واسع على لوحة المفاتيح تمثل هذه المؤلفة بداية وتمهيد لعزف أسلوب الفالس هن لثوبان بصوره مبسطه. تبدأ من أناكروز م (1 ) بالعزف بكلتا اليدين في صورة قفزات أوكتاف في حركة عكسية وهذا غالبا أسلوب موسيقى الفالس عند شوبان وبرامز •

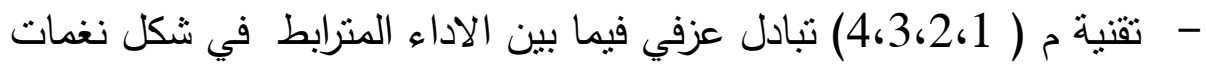
Staccato مفردة و الاداء المتقاطع وهو عبارة عن نغمات مزدوجة بأسلوب 
وهنا يجب إظهار التباين بينهما أثناء العزف كما يجب أداءهما بخفة وبالترقيم المدون من قبل المؤلف لإتقان أدائها ولإيضاح التباين بينهما. كما يراعى الوضع الصحيح للبيدال عند عزف النغمة الاولى ورفع الرجل عن البيدال عند عزف النغمة الثانية ـ كما بالثكل التالي:

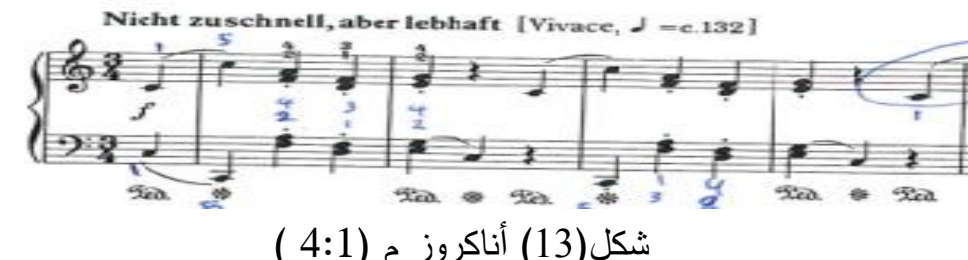

و نوضح الباحثة طريقة وضع البيدال كما يلى.

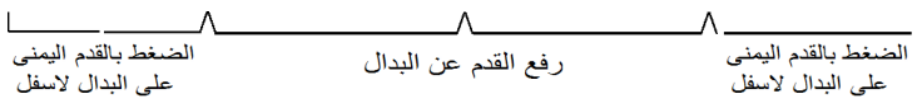

شكل ( 14 ) طريقة وضع البدال

تقنيه قفزة مسافة عشره من دو الوسطى الى مى سوبرانو صعودا في اليد اليمنى م (4) مستخدما القوس اللحني القصير slur كما تعزف اليد اليسرى في الباص قفزه مسافة عشرة نغمات صعودا بأسلوب Staccato العزف متقطع ثم تؤدى النغمة الاخرى باستخدام علامة الاكسنت (>) و تشير لأداء النغمة بشدة بالضغط عليها وهنا يجب المراعاة فى اظهار التباين بين العلامات لوضوح الاداء مع الدقة فى استخدام علامات البيدال لإظهار التعبير المطلوب كما بالثكل التالي

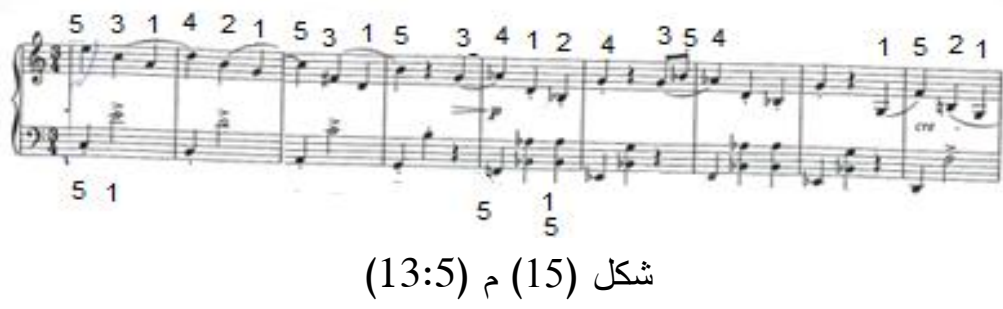


يجب مراعاه تكرار ققزات مسافة العشرة عدة مرات في م ( 6، 7، 13 ) ) وهذه القفزات تمنل صعوبة بالنسبة للعازف عند الاداء وللتغلب على هذه الصعوبة تم عمل تمرين مقترح من قبل الباحثة لسهوله الاداء.

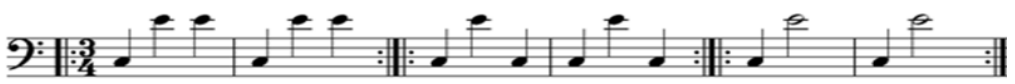

شكل (16) تمرين لأداء قفزات مسافة العشرة

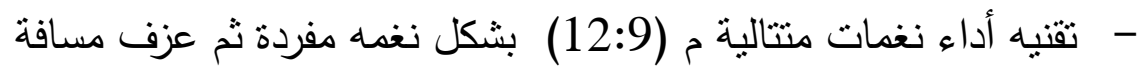

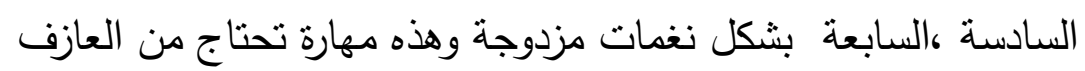
الانتقال والقفزات السريعة للنغمات المزدوجة لذا تقترح الباحثة الاداء بترقيم الاصابع لسهوله الاداء كما بالثكل التالي.

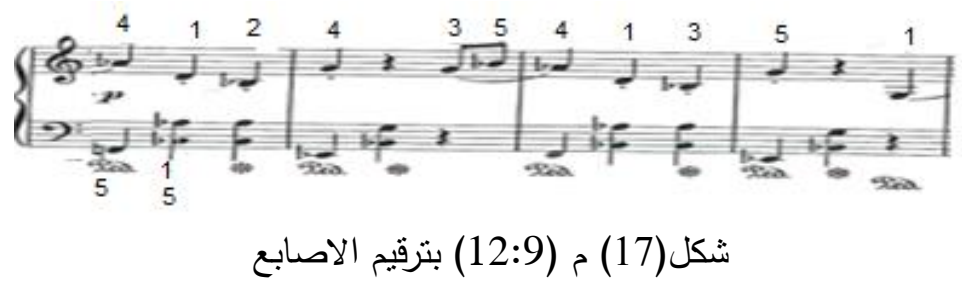

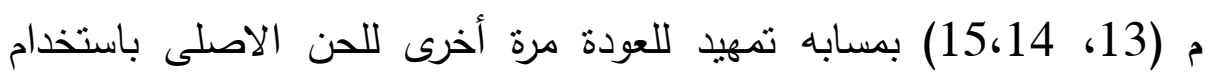

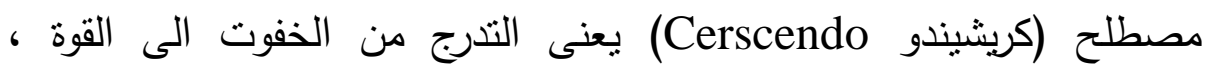
(ديمينوندو (Diminuendo) الخفوت، poco Rit-tempo يعنى التدرج في البطء ثم العودة للسرعة الأصلية م (17) م (16،15 ) يراعى العزف باليد اليمنى في صوت الباص لاستخدام

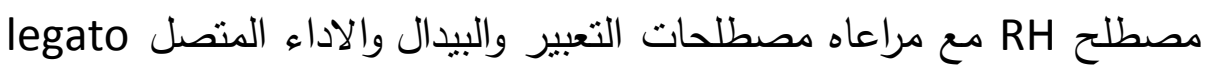
في اليد اليمنى فى صوت الباص.

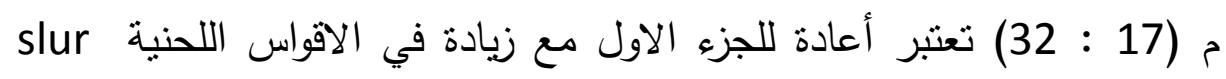

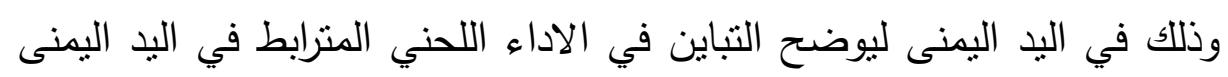
وعزف النغمة بأسلوب الضغط القوى(>) وقد ثم شرح هذه التقنية بمنمنمه رقم النداء 
(6) م (32:29) عبارة عن لحن غنائي لختام المؤلفة ليوضح سمه المؤلفة وهى الاسلوب الراقص لموسيقى الفالس. تعليق الباحثة :

ترى الباحثة أن هذا العمل من أكثر الاعمال التي تساعد على التدريب على مسافة العشرة ، وتقنية القوس اللحني القصير slur ، عزف مسافة السادسة ،السابعة بشكل نغمات مزدوجة ، مع الدقة في استخدام مصطلحات التعبير .

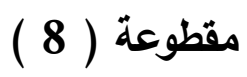

FORM Analysis أولا : التحليل البنائى

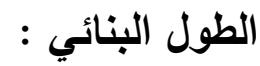

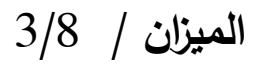
السلم : دو / الكبير 24

$$
\text { النسيج : هيموفوني }
$$
A | B | A' : الصيغة أسلوب الاداء : Ruhig,ausdrucksvoll شديد التعبير عن الاحاسيس و : ش العواطف ، الاداء الهادئ

\section{التظليل ومصطلحات التعبيز :}

الخفوت الى القوة ، (ديمينوندو Diminuendo)

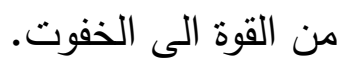
البيدال: أستخدم المؤلف البدال طوال المؤلفة لأثراء اللحن واضفاء جو الفالس على المؤلفة . تحليل الأداء Performance Analysis : اللحسن والتقتيات الأدائية: تتطلب هذه المؤلفة العزف المعبر وبهدوء ، تؤدى المدونة بخط لحنى مترابط The Melodic line و ذلك لوجود التتابع اللحني. 
الجزء A: يبدأ من م (8:1) وهو عبارة عن ألحان غنائية قصيرة منبادلة ما بين اليد اليمنى واليد اليسرى فى شكل أقواس لحنية قصيرة . - تقنيه أداء اللحن المتبادل ما بين اليد اليسرى و اليد اليمنى يجب اليب مراعاه

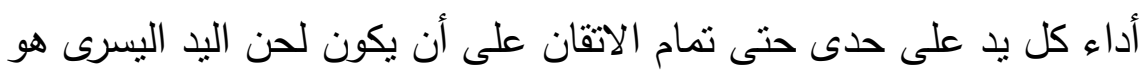

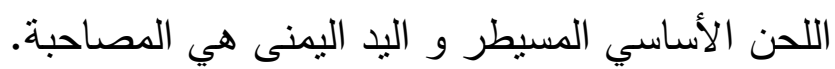
- كثرة الاقواس اللحنية في هذه المنمنمة يتطلب الاداء باستخدام البدال المتصل legato pedaling - لعزف الاقواس اللحنية بالثكل الصحيح لابد من الاداء بترقيم الاصابع من اقتراح الباحثة لسهوله الاداء كما بالثكل التالي •
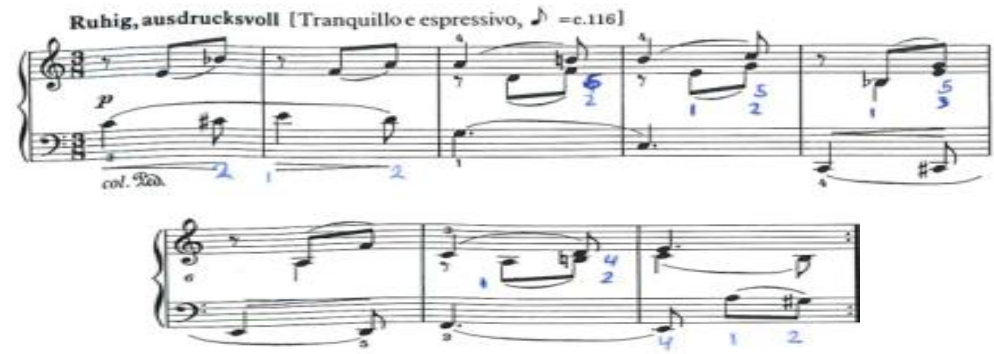

شكل ( 18) م (8:1) بالترقيم المقترح من الباحثة

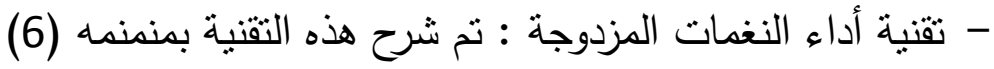

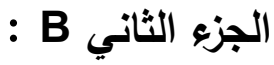

يبدأ من م (9: 16) يعتمد هذا الجزء على التنقلات اللحنية الكثيرة بين

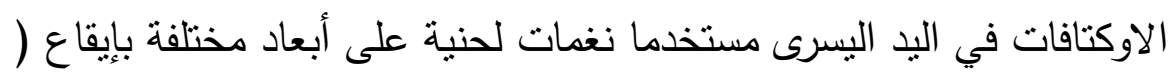
• • مع الرباط اللحني القصير slur مما يستلزم العزف بترقيم الاصابع المقترح من الباحثة لسهوله الاداء كما بالثكل التالي. 

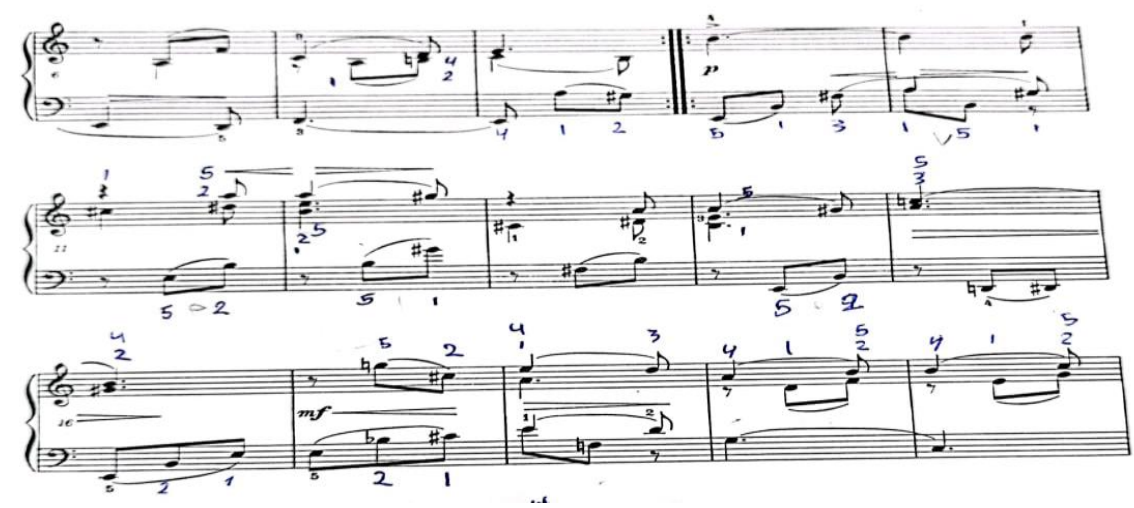

شكل ( 19) م (9: 16) بالترقيم المقترح من الباحثة

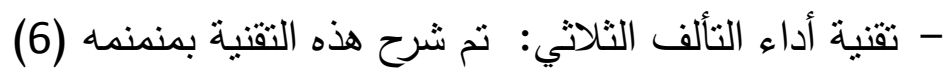

يبدأ من م (19: 24) وينتهى بققله تامه سلم دو/ك وهو أعادة للجزء الاول مع بعض التتمية اللحنية لإثراء اللحن. تعليق الباحثة : نرى الباحثة أن هذا العمل من أكثر الاعمال التي تساعد على التدربب على تقنية القوس اللحني القصير slur ، التنقلات اللحنية الكثيرة ما بين الاوكتافات في اليد اليمنى و اليسرى، اتقان التبادل العزفى ما بين اليدين.

\section{نتائج البحث}

بعد اجراء الدراسـة التحليليـة العزفيـة للعينهـه المختارة من مؤلفات المقطوعات القصيرة "المنمنمـات" عند المؤلف كيرشنر وعددها (4) مؤلفات من عدد (15) مؤلفه أستعرضت الباحثة نتائج البحث في جدول يتضمن التحليل البنائي لكل المؤلفات للوقوف على المستوى التدريسي الملائم للطلاب.

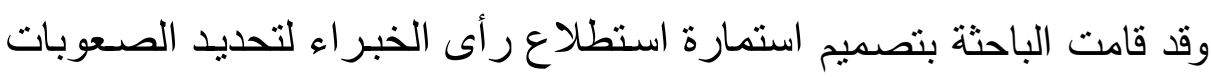

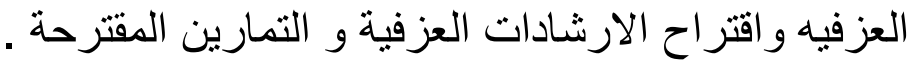


وبعد الدراسة التي قامت بها الباحثة وبعد الانتهاء من استعراض الجزء النظري و التطبيقي توصلت الباحثة الى النتائج التي تجيب على تساؤلات البحث كما يلى:

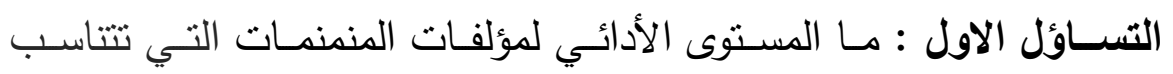
والمستوى التدربسي للمتعلمين؟ تمـت الاجابـة على هذا التسـاؤل مـن خـلال الدراسـة المسـحية و الاسـطنلاعية للمؤلفات عينه البحث في جدول يتضمن التحليل البنائي لكل المؤلفات للوقوف على المستوى التدريسي الملائم للطلاب. التساؤل الثانى : ما التقنيات العزفية التي يمكن اكتسابها من خـله التحليل العزفى لمؤلفات المقطوعات القصيرة عند كيرشنر؟ المانه تمت الاجابـة على هذا التسـاؤل مـن خـلال التحليل العزفى لعينه البحث ولقد فئد ظهرت عدة تقنيات عزفية بمكن الاستفادة منها في رفع المستوى العزفى بالنسبة للطالب منها - استخدام النغمات الممتدة بكثرة - كثرة التتوع بين المفاتيح كمفتاح صول ، فا. - اسـتخدم نمـوذج إيقـاعي متكرر مـع التصـوير للألحسان في طبقات صـوتية مختلفة . - اسـتخدام التألفـات الثلاثيــة الهارمونيـة و الاوكتافـات - اسـتخدام المسـافات

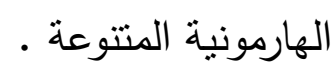

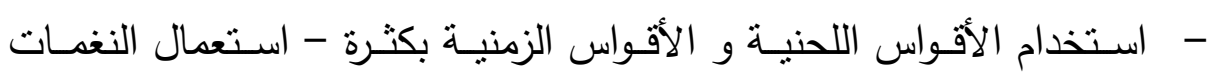

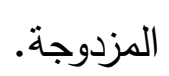

التسـاؤل الثالث: ما الصعوبات التكنيكية والتعبيرية في مؤلفات المقطوعات القصيرة عند كيرشنر وما الحلول المقترحة لأدائها ؟ 
تمت الاجابة على هذا التساؤل من خلال عمل استمارة استطلاع رأى الخبراء في الصعوبات العزفية والارشـادات والتمارين المقترحة من خلال التحليل البنائي والتحليل العزفى لعينه البحث . تفسير نتائج البحث

من خلال الدراسـة الاستطلاعية و المسحية و التحليل البنائي لعينه البحث وجدت الباحثة أن المقطوعات

القصيرة عند كيرشنر تحتوى على مجموعه متتوعة من الاسـاليب التي أستخدم

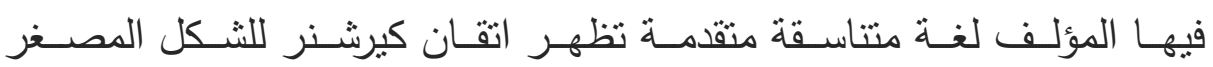
للمقطوعات كل مقطوعة لها شخصية فربدة خاصسه بها فيما يتعلق بالهارمونية والمحتوى اللحني والثكل الموسيقى كما تتميز هذه المقطوعات بأسلوب رقصـة الفالس و بالتعبير و التوازن بين اليدين عند العزف وقد اتققت نتائج البحث مـع الدراسـات السـابقة كدراسـة آيـة يوسف محمد محمد التى أثنارت الى استخدام مجلد دنيس آجاى التعليمي لتحسين أداء دارسي آلة البيانو ، دراسة مروة عاطف سـامهه عبد الرحمن التي أشـارت الى المجلد الأول

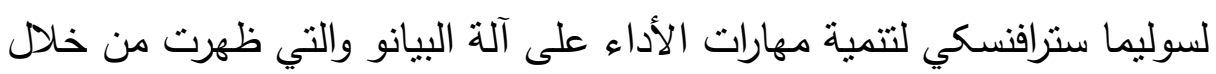
التمارين والتدريبات المقترحة التي تحتوى عليها تلك المؤلفات والتى تتمل عدة أهداف تعليمية تعمل على رفع مستوى أداء الطالب . التوصيات : (1) - n توصى الباحثة بما يلى : - ت توفير المـدونات الموسيقية لمؤلفـات المنمنمـات لالـة البيانو وذلك يعطى الدارس فرصة للاختبار ما يناسب مستواه . - ادراج مؤلفات كيرشنر من ضمن مناهج البيانو للكليات المتخصصة . 


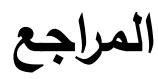

أولا : المراجع العربية

- آية يوسف محمد محمد : رساله ماجستير غير منشورة - كليه التربية

$$
\text { النوعية - جامعة عين شمس } 2018
$$

- - جابر عبد الحميد وأحمد خيرى كاظم : مناهج البحث فى التربية و علم

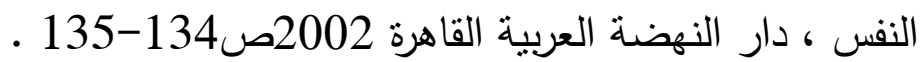

- شرين سمير محمود الجندي: بحث انتاج المؤتمر الدولي الاول (العلمي الثامن) كليه التربية الموسيقية - جامعه حلوان 2010.

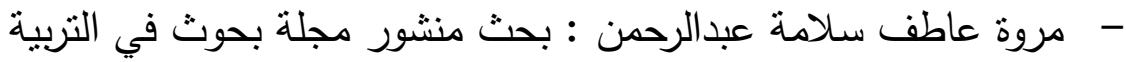

النوعية - العدد الثاني - جامعة المنيا 2016

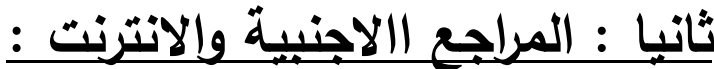

-CANDACE FISH :THEODOR KIRCHNER'S MINIATURES ‘OP 62A PEDAGOGICAL ANALYSIS, Norman, Oklahoma. 2020

-Luce, Robert, The Famous Pianists, New York, 1974, p135

-Sadie Stanly: " The New Grove" Dictionary of music and musicians vol 16, U.S.A , Macmillan limited, 1980p.282

- Slonimsky, Nicolas, Bakers Biographical Dictionary Of Musicians, Sixth Edition, Macmillan publishing Co. London, 1978, p 262 .

-www.almaniah.com/articles/view/2445

-http://www.visionofparadise.ch/a-music/history/kirchn.html

-https://ar.wikipedia.org/wiki

- https://www.wikiwand.com/de/Theodor_Kirchner

-https://econtact.ca/16_3/chippewa_miniature.html 


\section{ملخص البحث}

الاستفادة من مجلد المقطوعات القصيرة لثيودور كيرشنر لتحسين أداء الطالب على أله البيانو

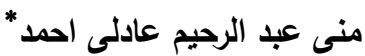

تعتبر المقطوعات الموسيقية لآلة البيانو من الركائز الأساسية و الهامه التي يينى

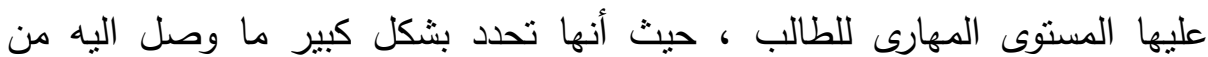
المهارات العزفيه التي تمكنه من الأداء الجيد وذلك لما تحويه من أهداف تربوية ومهارات تكنيكيه تتسم بسهوله الايقاع وجاذبيه اللحن حتى يصل الطالب للمستوى الفني المطلوب ، ومن امتله هذه المؤلفات مؤلفات المقطوعات القصيرة "المنمنمات "عند المؤلف الالمانى كيرشنر فهي تعتبر أضافه للمقررات الدراسية وبالرغم من كل هل

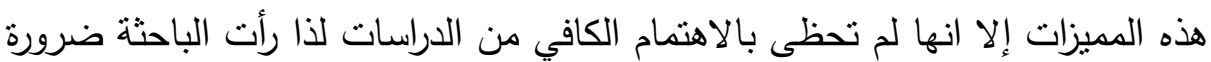
تتاولها بالدراسة و التحليل حتى يمكن الاستفادة منها لتحسين أداء الطالب على أله البيانو وقد هدفت تلك الدراسة الى عمل دراسة مسحيه لمجلد المقطوعات القصيرة مصنف 62 لكيرشنر وتصنيفها الى لثلاث مستويات الاستفادة من التقنيات العزفية

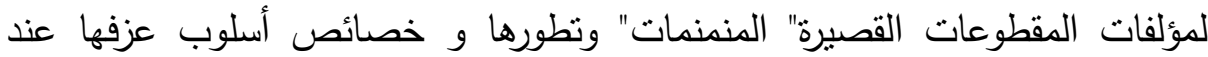
كيرشنر ، تحديد الصعوبات العزفيه، واقتراح الحلول بالتمارين والإرشادات العزفيه لتذليل تللك الصعوبات كما شملت أهمية البحث التعرف على مقطوعات جديدة من شأنها إثراء المناهج الدراسية وتتويعها وايجاد دراسة علمية يمكن الرجوع اليها في حاله الرغبة

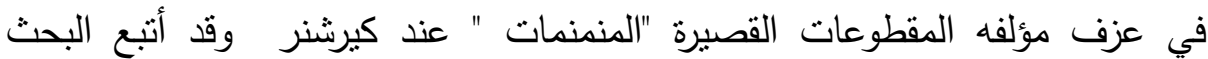
الحالي المنهج الوصفي (تحليل محتوى ) و أختتم البحث بنتائج البحث و التوصيات .

* استاذ البيانو المساعد- بكليه الثربية النو عية - جامعه جنوب الو ادي 


\section{To benefit from Theodore Kirchner's Short Pieces Folder to Improve Student Performance on the Piano}

\section{Mona Abd El Rahem Adly Ahmed*}

The musical compositions of the piano instrument are considered one of the main and important pillars upon which the skill level of the student is built, as it largely determines the playing skills that he has reached that enables him to perform well. This is because it contains educational objectives and technical skills that are characterized by ease of rhythm and attractive melody until the student reaches the required technical level. Examples of these works are the works of short pieces "miniatures" by the German author Kirchner, as they are considered an addition to the academic courses. Therefore, the researcher saw the need to study and analyze it so that it can be used to improve the student's performance on the piano This study aimed to make a survey study of the volume of short pieces of Kirchner's categorized 62 and categorized them into three levels, taking advantage of the playing techniques of the compositions of short pieces "miniatures", their development, and the characteristics of Kirchner's playing style, Identifying playing difficulties, and suggesting solutions with exercises and playing instructions to overcome these difficulties The importance of the research also included identifying new pieces that would enrich and diversify the school curricula and finding a scientific study that could be referred to in the event of a desire to play his composition of short pieces "miniatures" by Kirchner. The current research followed the descriptive approach (content analysis) and concluded the research with the research results and recommendation

*Assistant Professor of Piano - Faculty of Specific Education -

South Valley University 
مجلة البحوث فى مجالات التربية النوعية

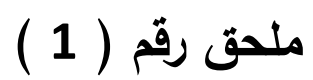

جدول التحليل البنائي و العزفي للمقطوعات التى تناسب الطالب المتوسط المستوى

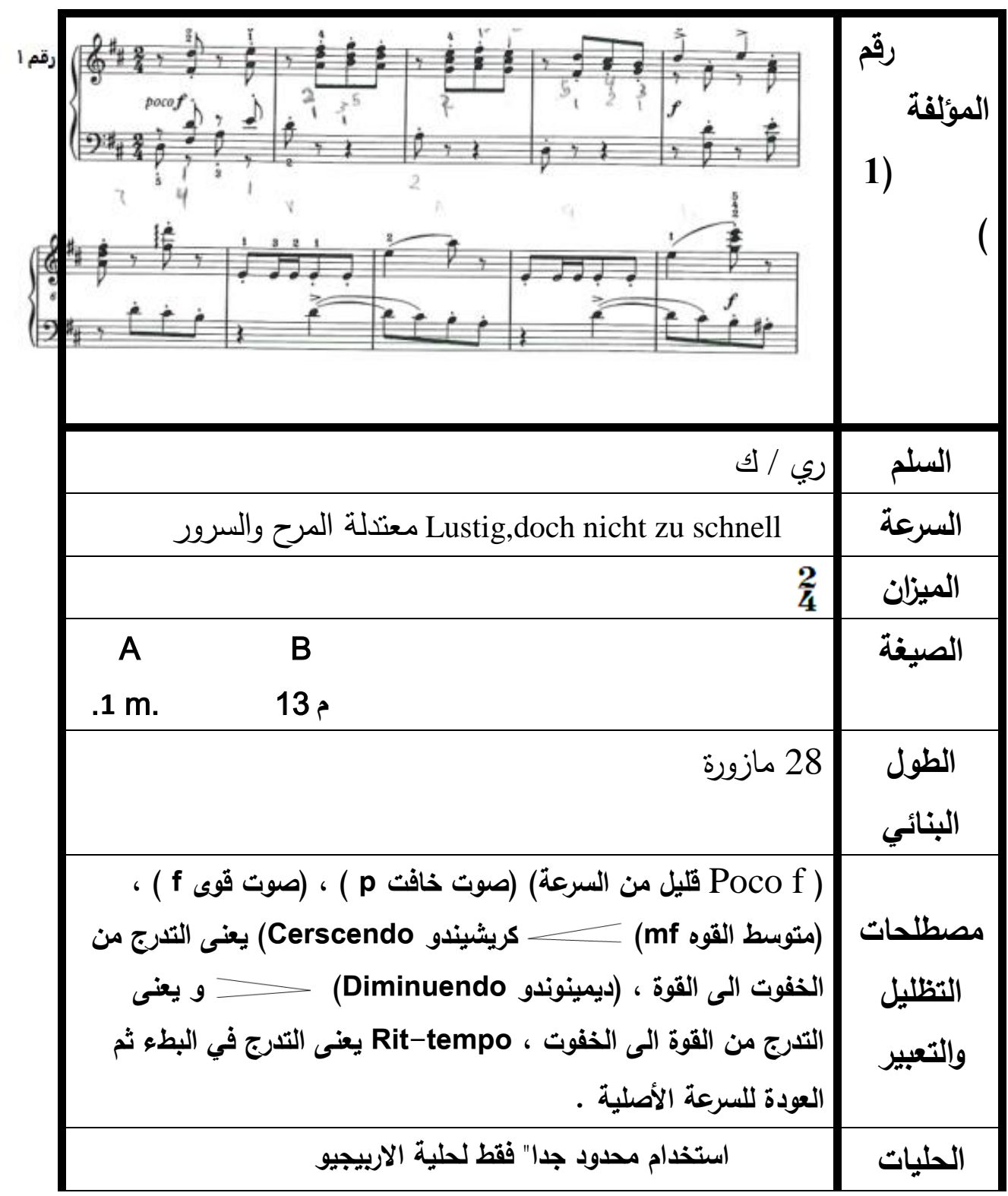


مجلة البحوث في مجالات التربية النوعية

البيدال

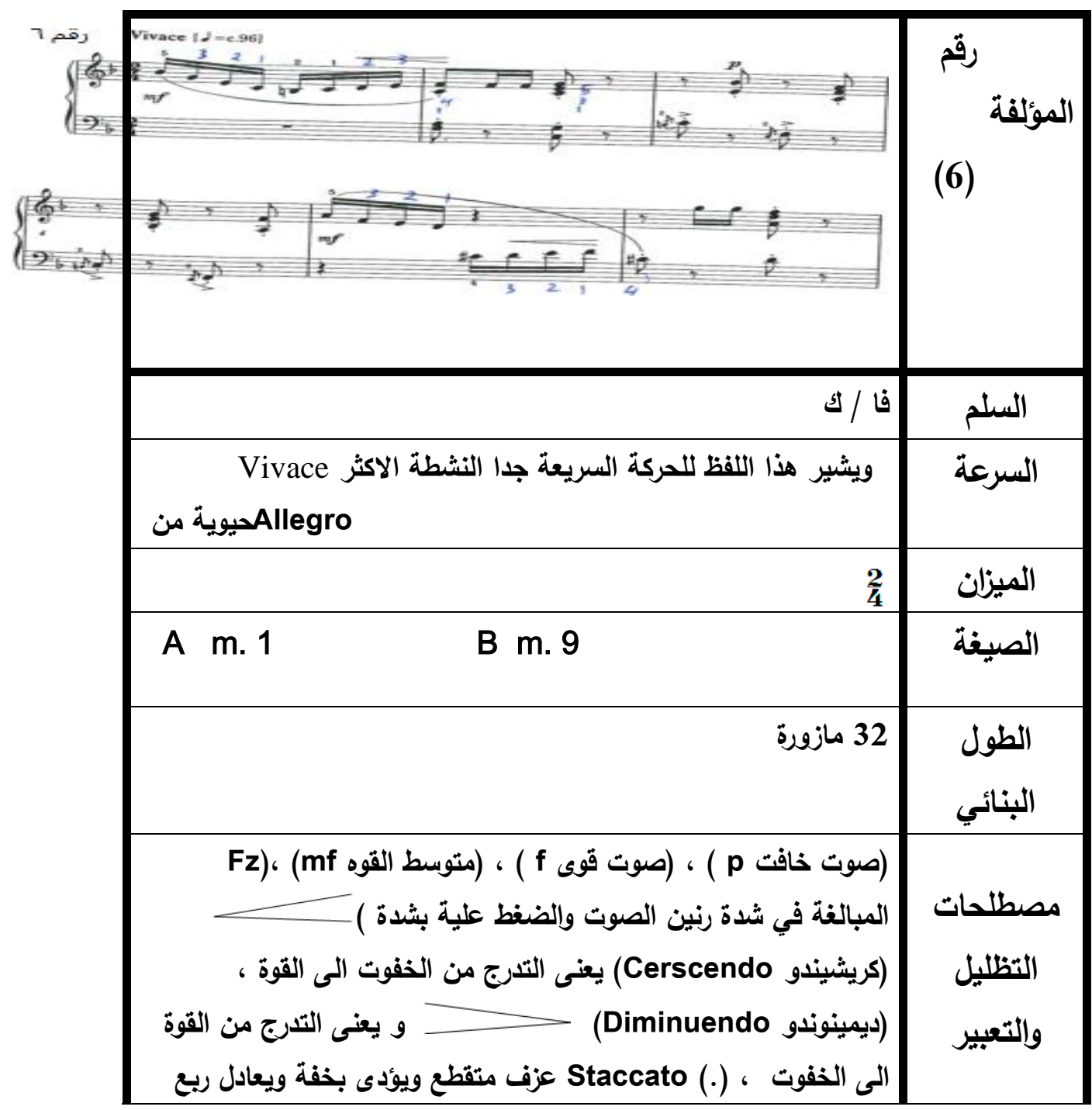


مجلة البحوث في مجالات التربية النوعية

القيمة الزمنية للعلامة ، Rit-tempo يعنى التدرج في البطء ثم العودة للسرعة الأصلية .

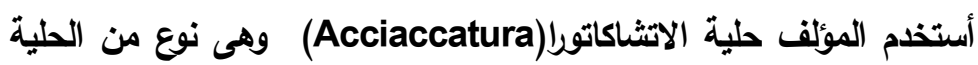
الحليات

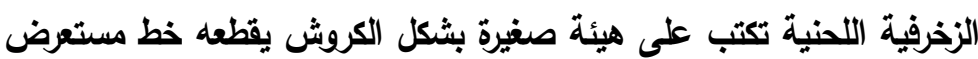

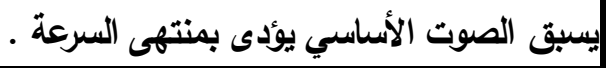
لم يستخدم البيدال البيدال تصلح للطالب المنوسط المستوي

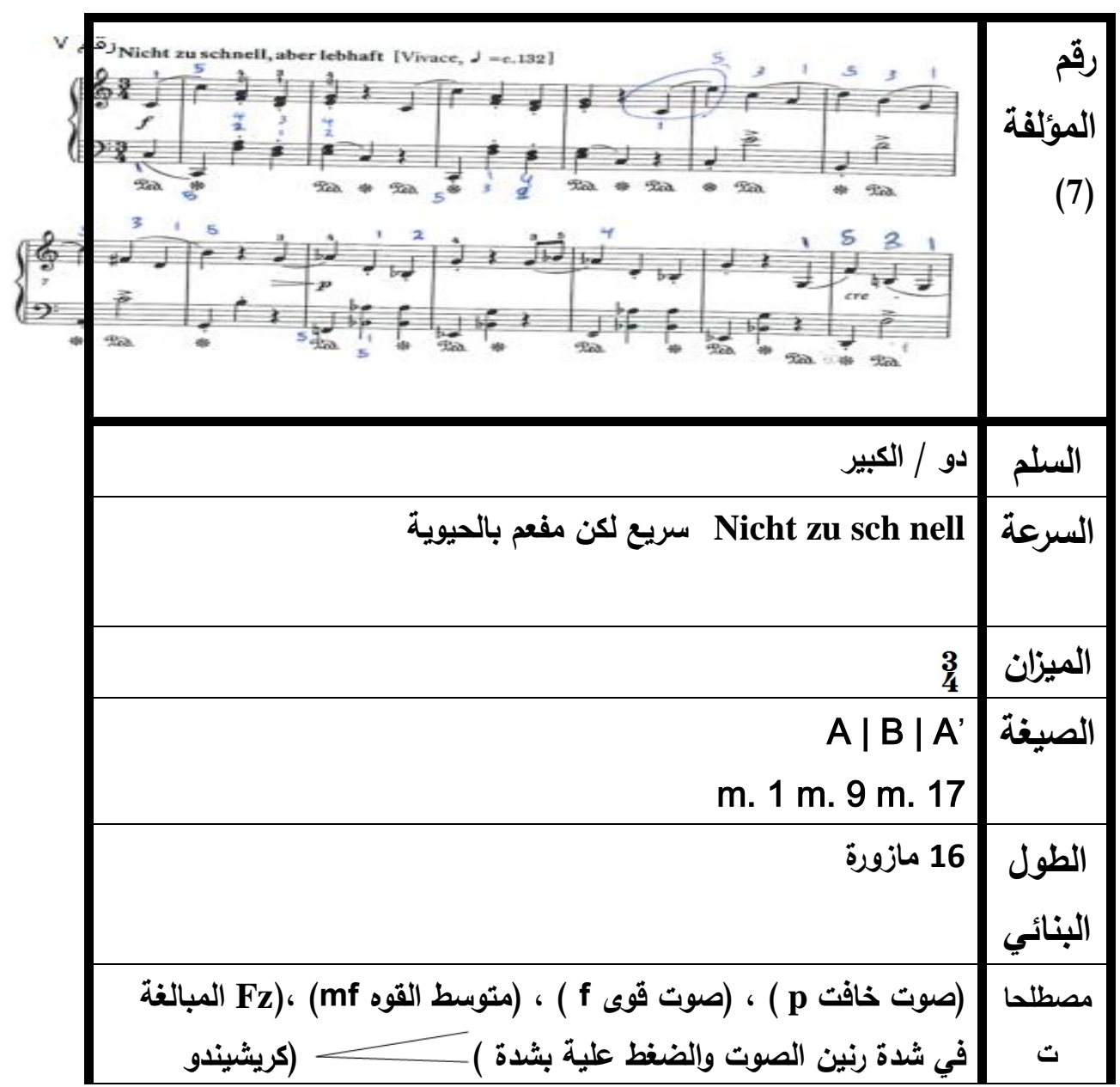




\begin{tabular}{|c|c|}
\hline 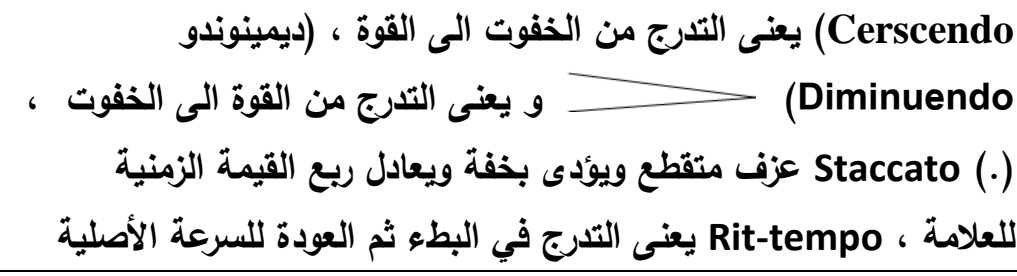 & والتظعبل \\
\hline لم يستخدم المؤلف أى نوع من الحليات & الحليا \\
\hline على أستخدم المؤلف البيدال بكثرة لأثراء اللحن واضفاء جو الفالس & البيدا \\
\hline تصلح للطالب المتوسط & التدريسيتي \\
\hline
\end{tabular}

\begin{tabular}{|c|c|}
\hline 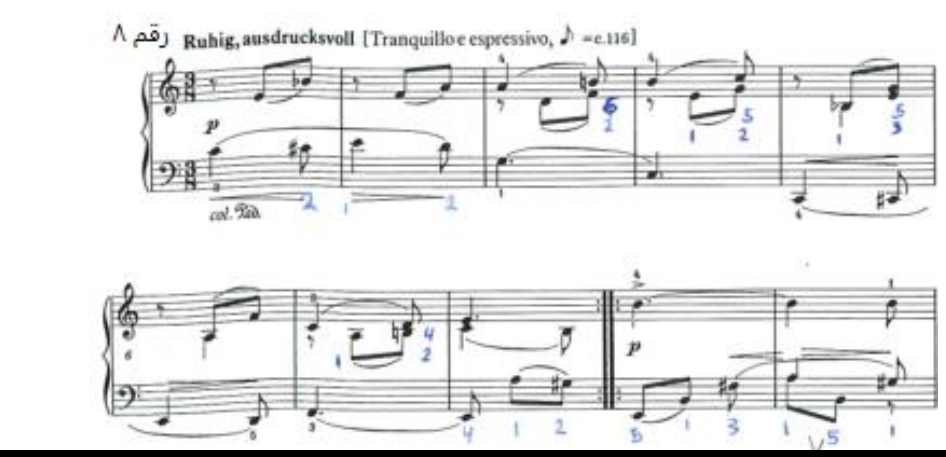 & المؤلفة رقم \\
\hline دو / ك & السلم \\
\hline 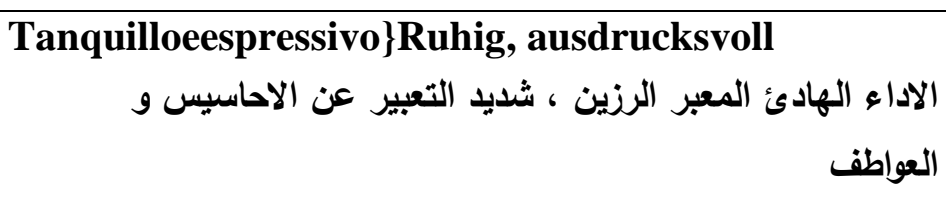 & السرعة \\
\hline $\begin{array}{l}3 \\
4 \\
\end{array}$ & الميزان \\
\hline $\begin{array}{c}\mathrm{A}|\mathrm{B}| \mathrm{A}^{\prime} \\
\mathrm{m} .1 \mathrm{~m} .9 \mathrm{~m} .17\end{array}$ & الصيغة \\
\hline 24 مازورة & الطول \\
\hline
\end{tabular}


مجلة البحوث في مجالات التربية النوعية

\begin{tabular}{|c|c|}
\hline & البنائي \\
\hline 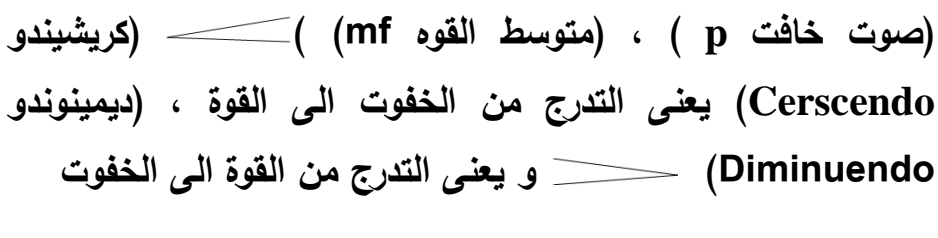 & مصطلحات التظليل \\
\hline لم يستخدم المؤلف أي نوع من الحليات & 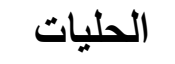 \\
\hline أستخدم المؤلف البيدال بكثرة لاثراء اللحن & البيدال \\
\hline تصلح للطالب المتوسط & المستوي \\
\hline
\end{tabular}

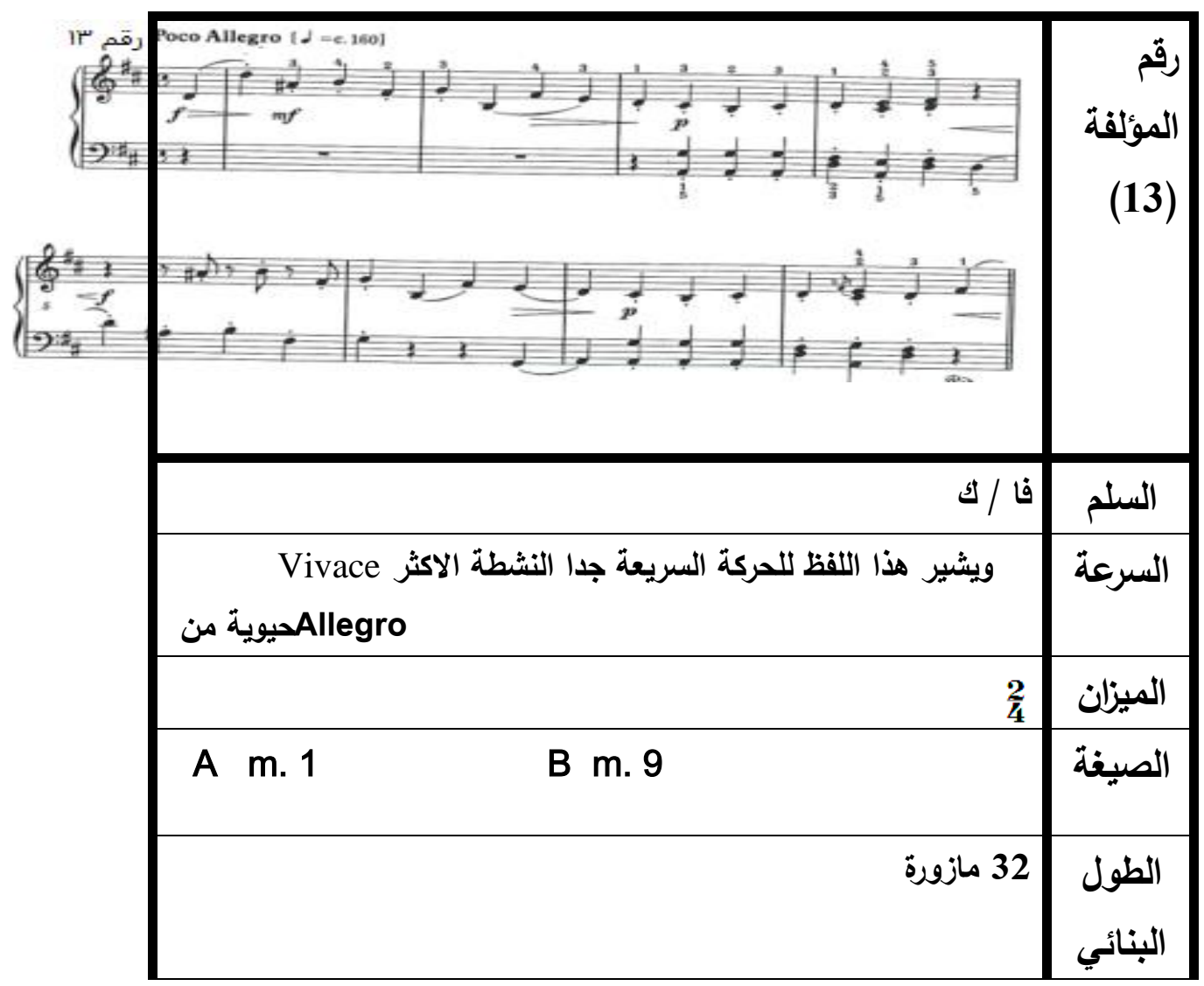




\begin{tabular}{|c|c|}
\hline 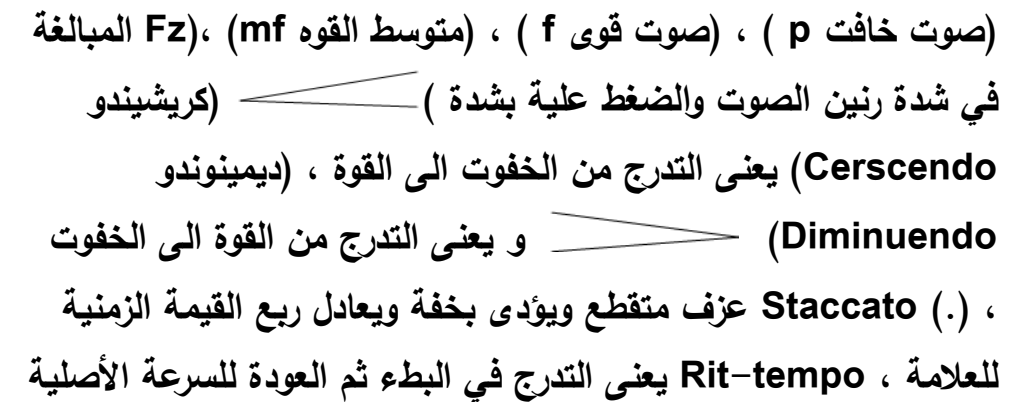 & مصطلحا \\
\hline 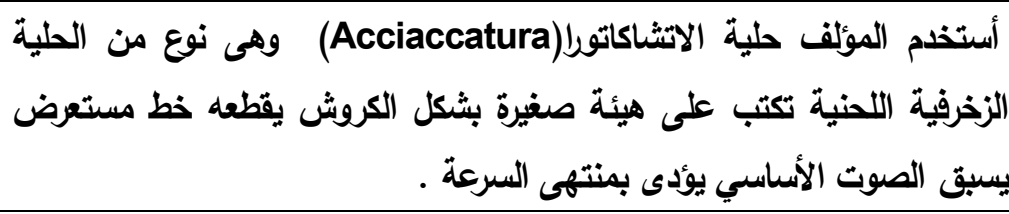 & الحليات \\
\hline لم يستخدم البيدال & البيدال \\
\hline تصلح للطالب المتوسط & التدريسي \\
\hline
\end{tabular}


جدول التحليل البنائي و العزفي للمقطوعات التى تناسب الطالب فوق

\section{المتوسط}

\begin{tabular}{|c|c|}
\hline 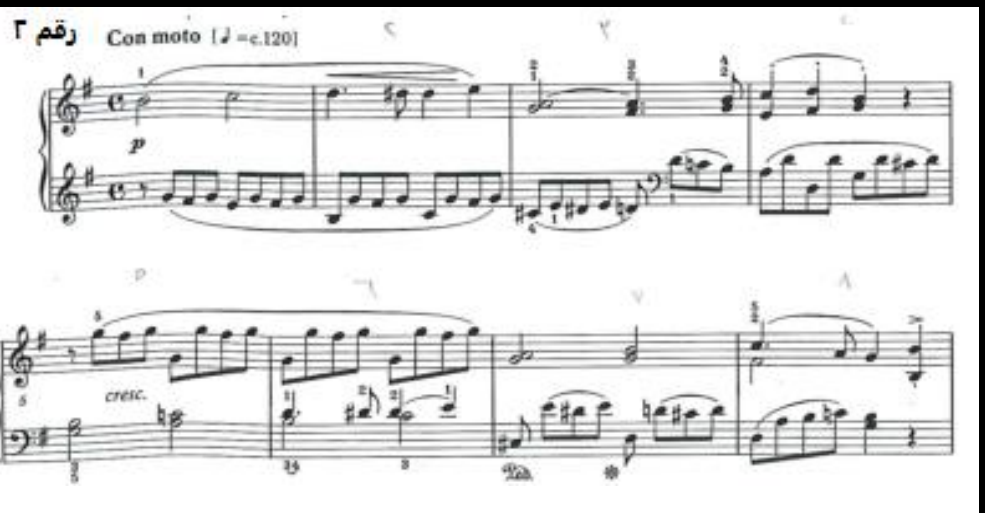 & قامث \\
\hline صول / ك5 & 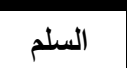 \\
\hline Con moto تعنى بتذفق ، بحركة ، بحرارة & 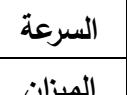 \\
\hline $\begin{array}{l}\text { A }|B| A^{\prime}|B| A^{\prime} \\
\text { m. } 1 \text { m. } 9 \text { m. } 17 \text { m. } 25 . \mathrm{m} .33\end{array}$ & الصيغة \\
\hline 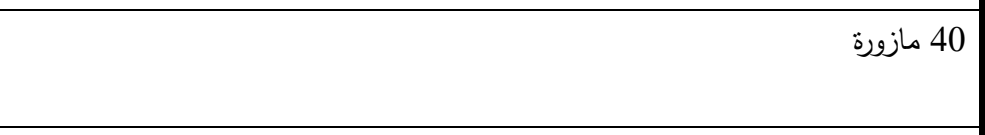 & البنائي \\
\hline 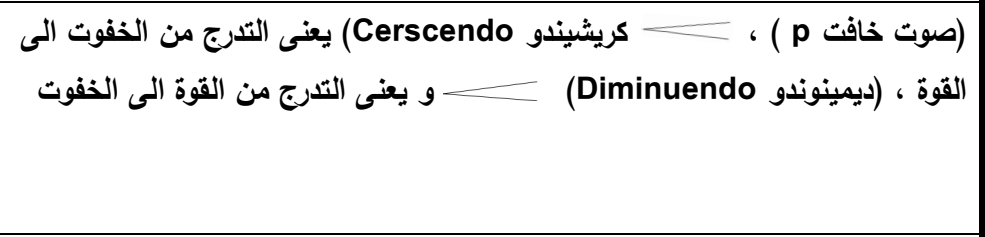 & مصطلما \\
\hline لم يستخدم أي نوع من الحليات لكثرة التدفق اللحني & الحليات \\
\hline استخدم المؤلف البيدال في حدود ضيقة & 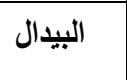 \\
\hline تصلح للطالب فوق المتوسط & 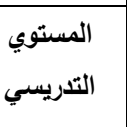 \\
\hline
\end{tabular}




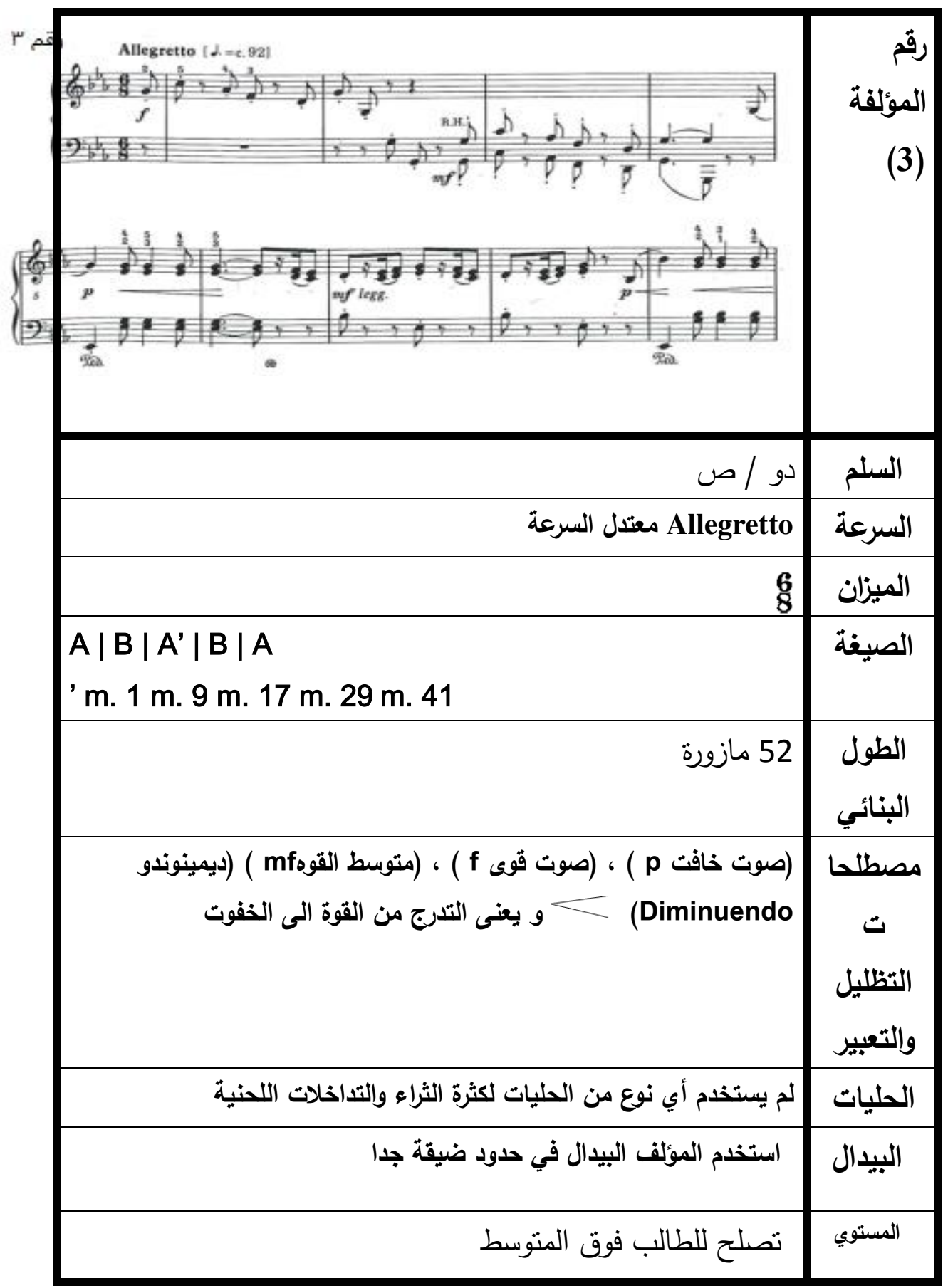




\begin{tabular}{|c|c|}
\hline 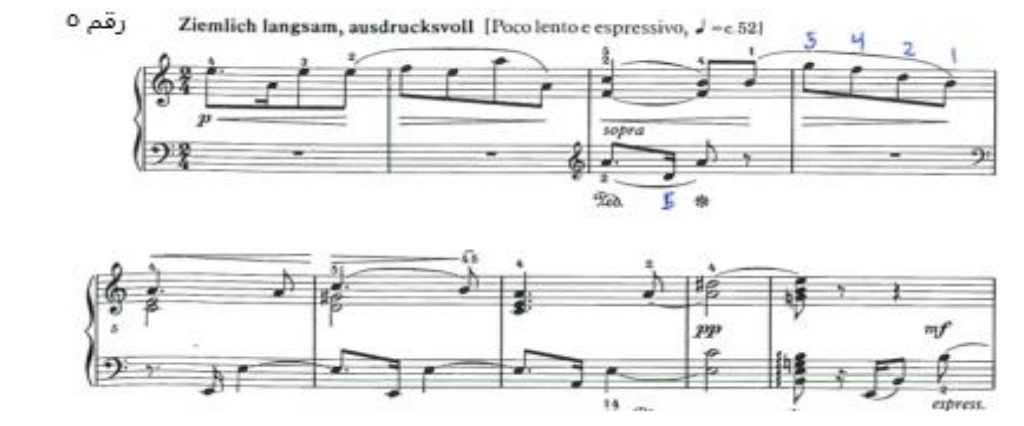 & رقم \\
\hline لا / ص & السلم \\
\hline 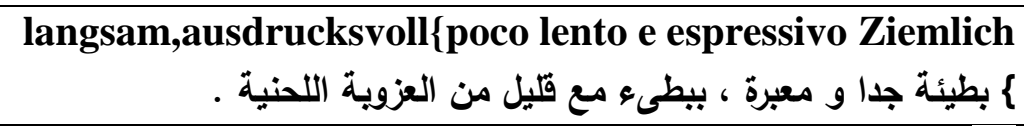 & السرعة \\
\hline $\begin{array}{l}\mathbf{2} \\
\mathbf{4}\end{array}$ & الميزان \\
\hline $\begin{array}{llll}\text { A } & \text { B } & \text { I } \\
\text { m. } 1 \mathrm{~m} .31 \mathrm{~m} .39 & & & \end{array}$ & الصيغة \\
\hline 47 مازوره & البنائي \\
\hline 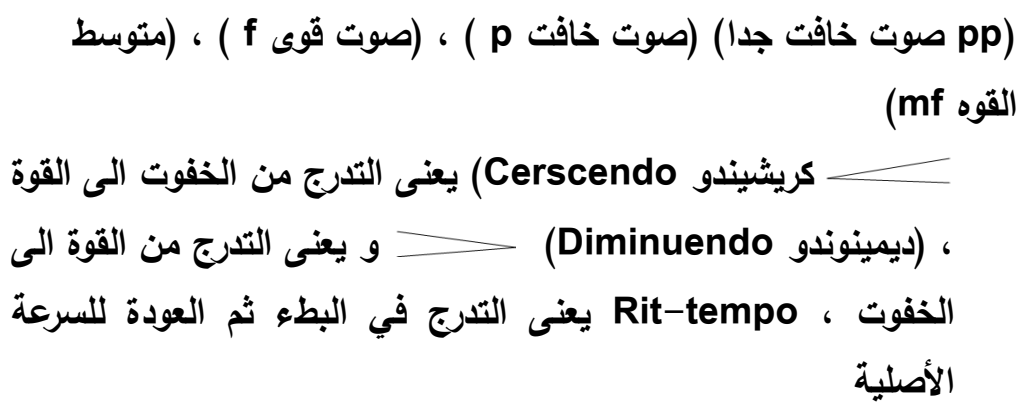 & مصطلحا \\
\hline أستخدم المؤلف حلية الاريجيو & الحليات \\
\hline أستخدم المؤلف البيدال بكثرة & البيدال \\
\hline تصلح للطالب فوق المتوسط & 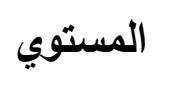 \\
\hline
\end{tabular}




\begin{tabular}{|c|c|}
\hline 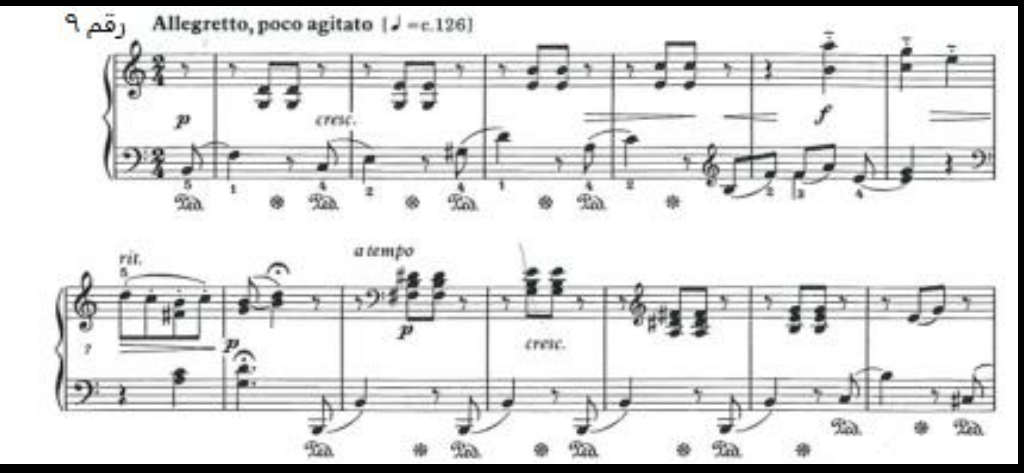 & رقم \\
\hline دو / ك & السلم \\
\hline 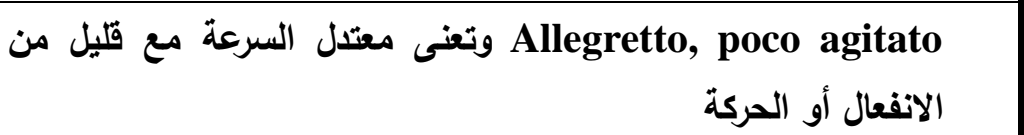 & السرعة \\
\hline 2 & 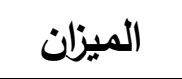 \\
\hline $\begin{array}{l}\text { A } \quad \text { B } \\
\mathrm{m} .1 \mathrm{~m} .17\end{array}$ & الصيغة \\
\hline 36 مازورة & الطول \\
\hline 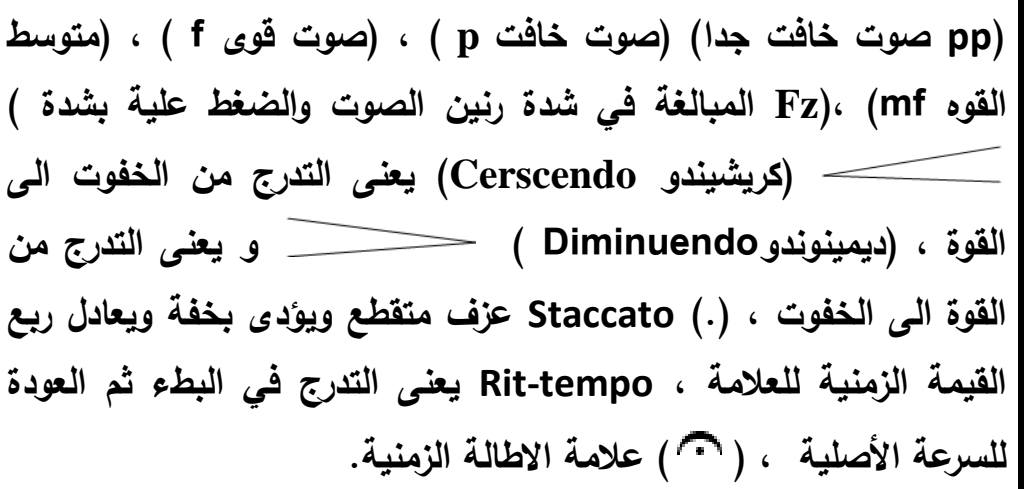 & مصطلحات \\
\hline لم يستخدم المؤلف أي نوع من الحليات & الحليات \\
\hline أستخدم المؤلف البيدال بكثرة لاثراء اللحن & البيدال \\
\hline تصلح للطالب فوق المتوسط & المستوي \\
\hline
\end{tabular}




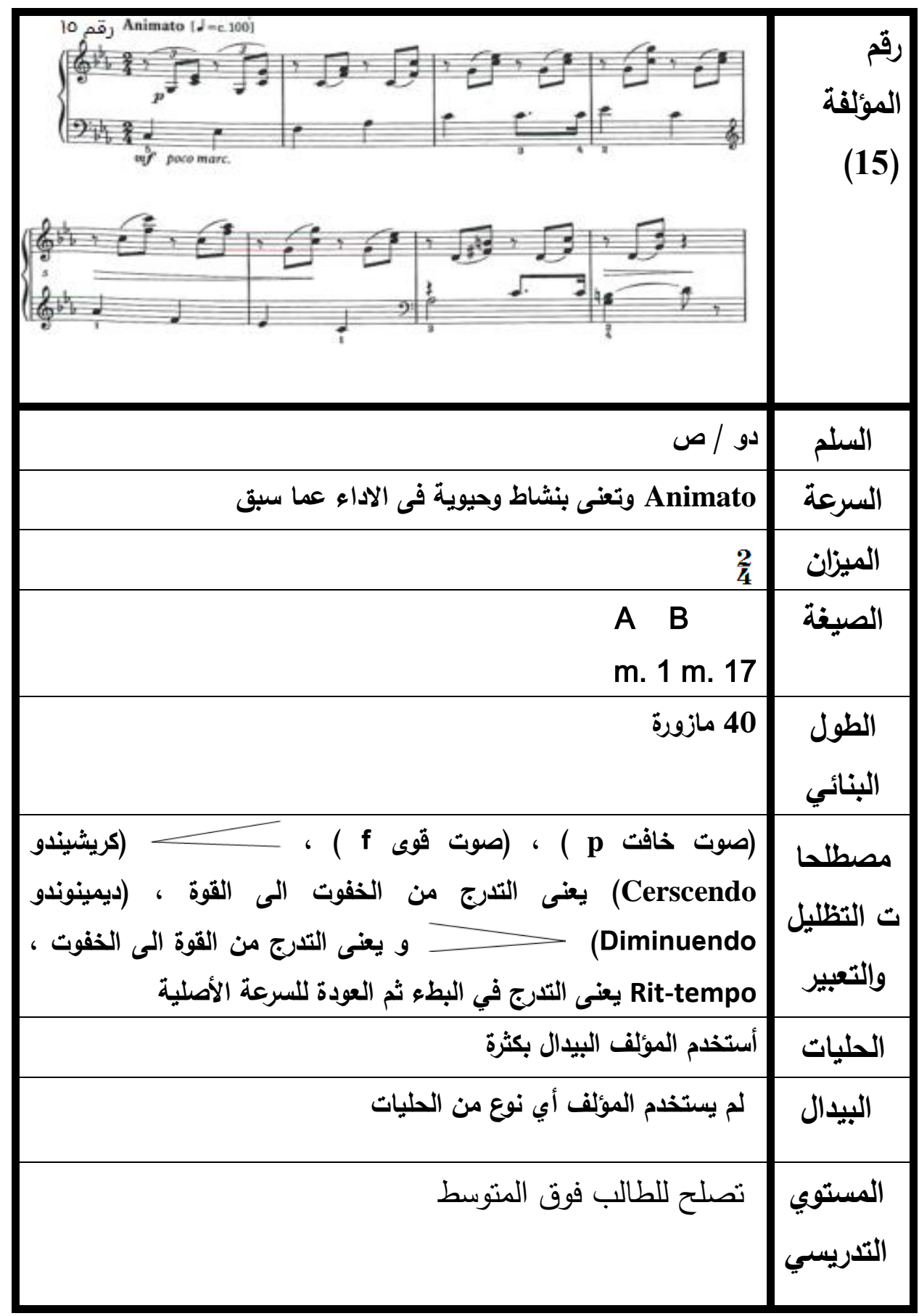


جدول التحليل البنائي و العزفي للمقطوعات التى تناسب الطالب المتميز

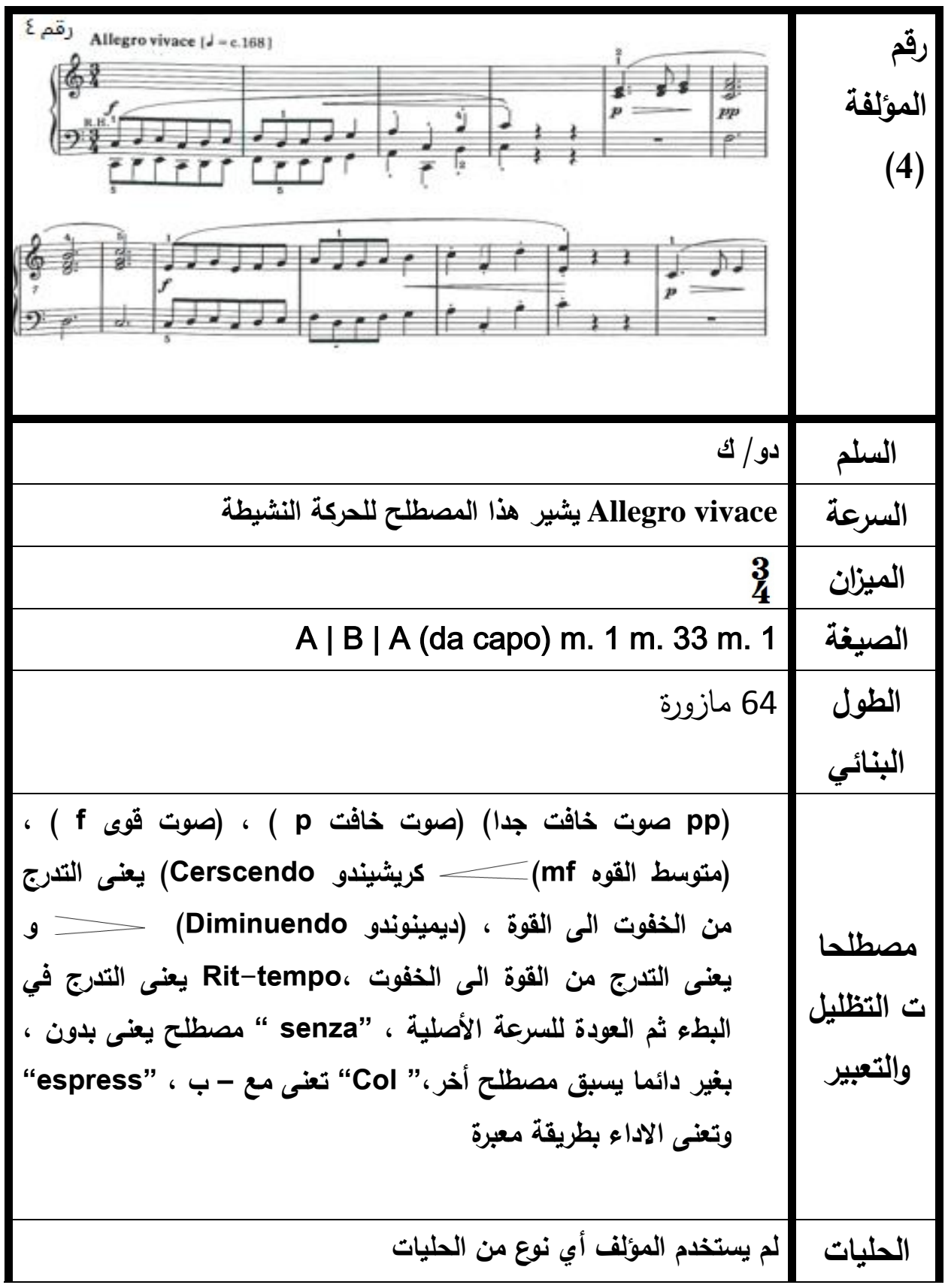


مجلة البحوث في مجالات التربية النوعية

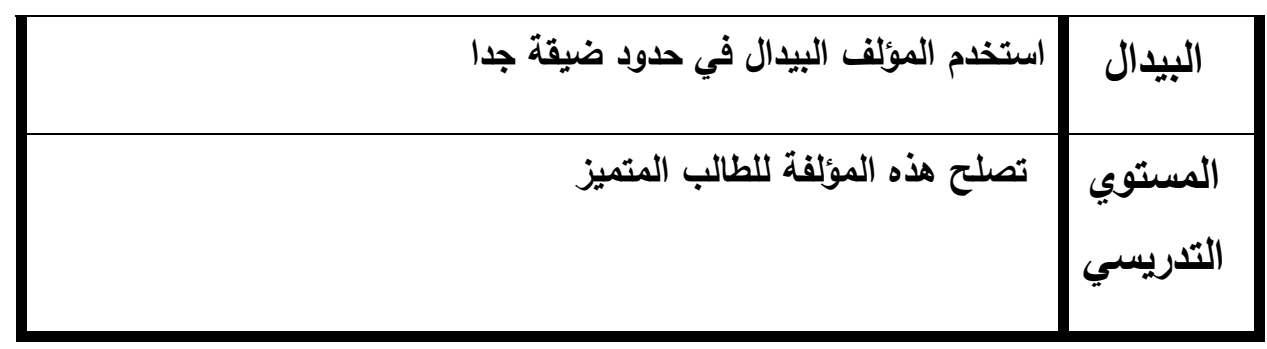

\begin{tabular}{|c|c|}
\hline 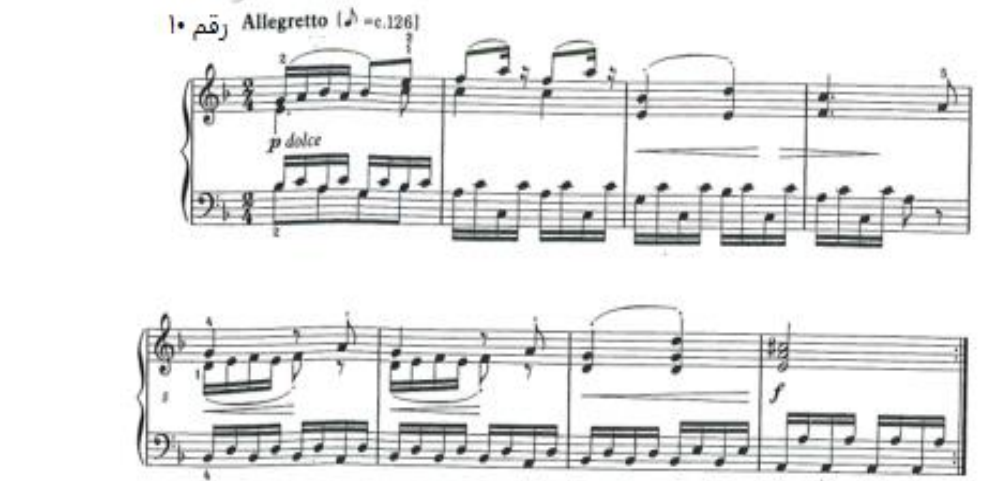 & المؤلفة \\
\hline فا / ك5 & 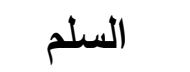 \\
\hline Allegretto معتل السرعة & السرعة \\
\hline$\frac{2}{4}$ & 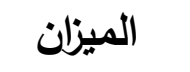 \\
\hline 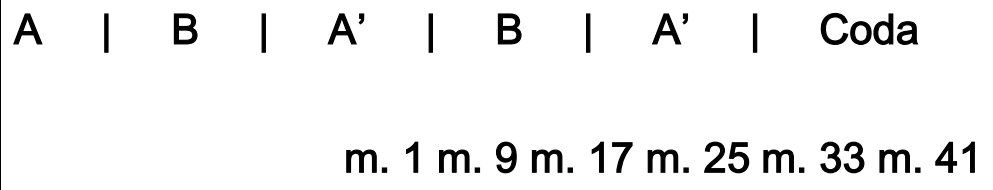 & الصيغة \\
\hline 48 مازورة & الطول \\
\hline 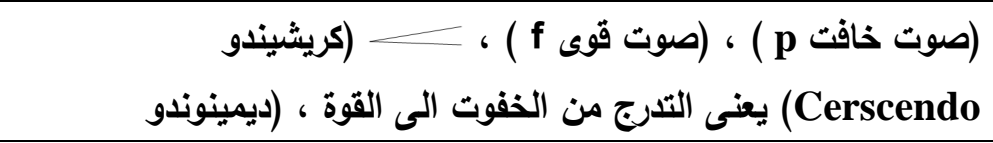 & مصطلحاث \\
\hline
\end{tabular}


مجلة البحوث في مجالات التربية النوعية

و يعنى التدرج من القوة الى الخفوت ، (.)

(Diminuendo

التظليل

Staccato والتععبيز للعلامة" dolce" يعنى هذا المصطلح الاداء بحلاوه استخدم المؤلف البيدال فى حدود ضيقة الحلياث

لم يستخدم المؤلف أي نوع من الحليات البيدال

تصلح هذه المؤلفة للطالب المتميز المستوي التدريسي

\begin{tabular}{|c|c|}
\hline 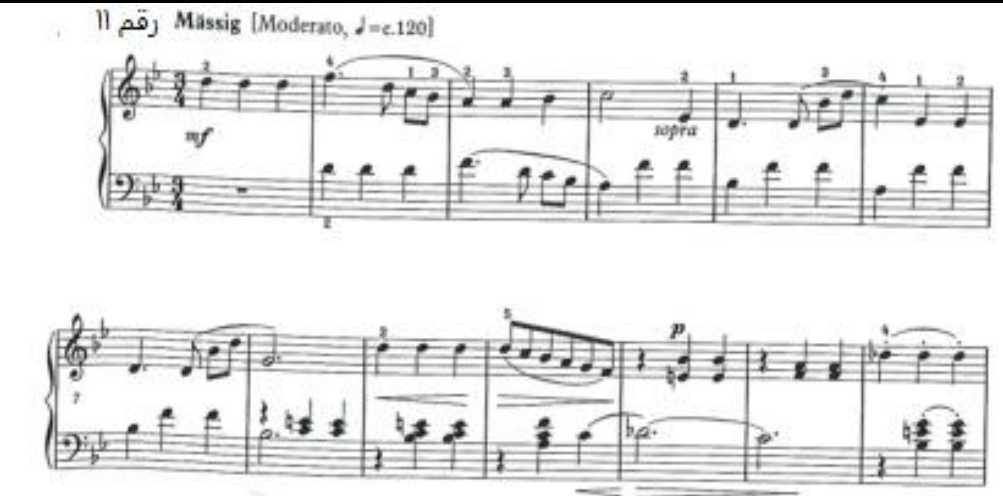 & المؤلفة \\
\hline مول/ ك & السلم \\
\hline Massig معتدل ، متوسط السرعة & \\
\hline $\begin{array}{l}3 \\
\mathbf{4} \\
\end{array}$ & 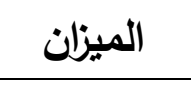 \\
\hline $\begin{array}{l}\text { A B } \\
\text { m. 1 m. } 17\end{array}$ & الصيغة \\
\hline 32 مازورة & الطول \\
\hline
\end{tabular}


مجلة البحوث فى مجالات التربية النوعية

\begin{tabular}{|c|c|}
\hline & البنائي \\
\hline 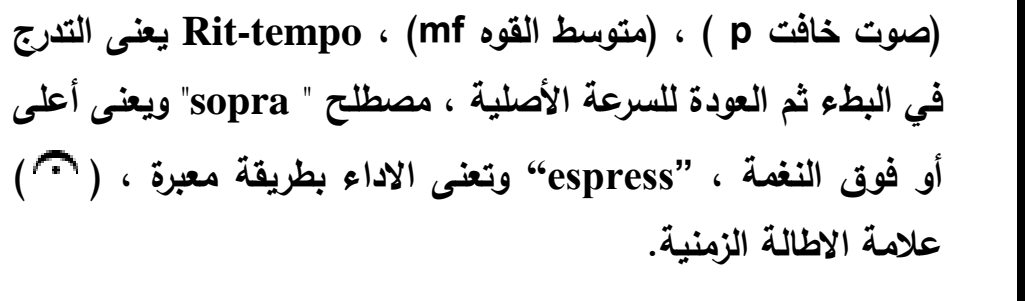 & مصطلحات \\
\hline أستخدم المؤلف البيدال فى حدود ضيقة & البيدال \\
\hline 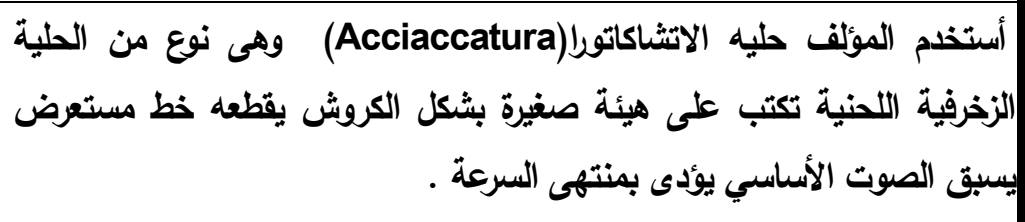 & الحليات \\
\hline تصلح هذه المؤلفة للطالب المتميز & المستوي \\
\hline
\end{tabular}

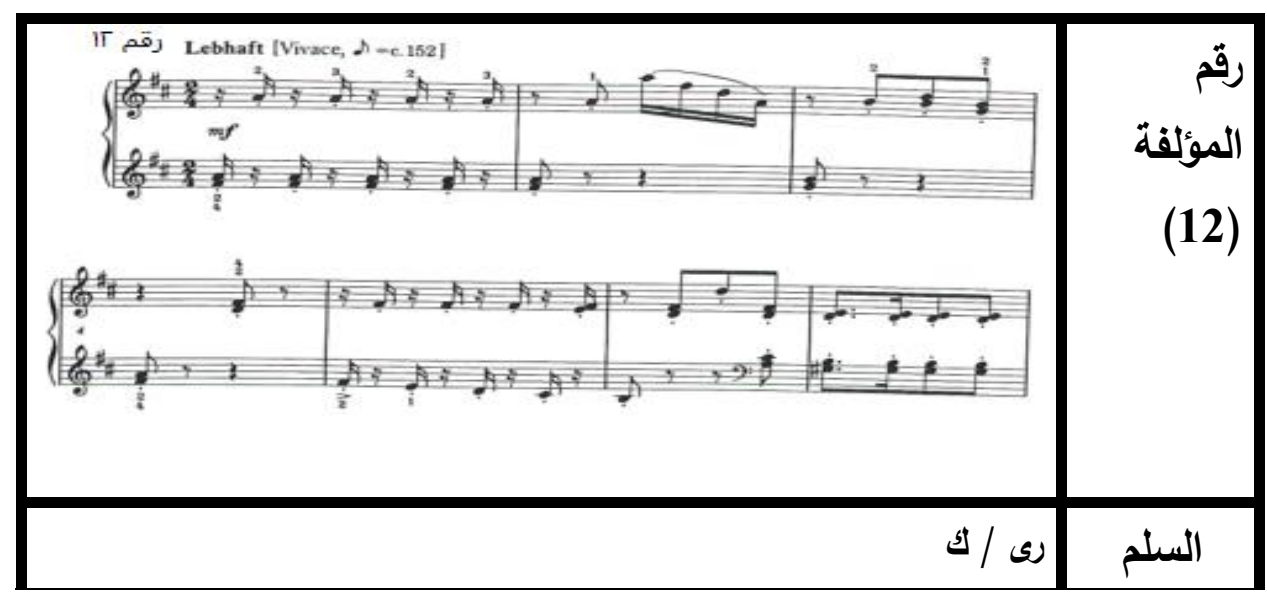


مجلة البحوث فى مجالات التربية النوعية

\begin{tabular}{|c|c|}
\hline Lebhaft تعنى سريعة جدا ونشيطه وأكثر حيويه & 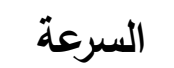 \\
\hline 2 & 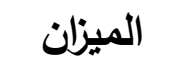 \\
\hline $\begin{array}{l}\text { B } \\
\text { m. } 1 \mathrm{~m} .17 \mathrm{~m} .33\end{array}$ & 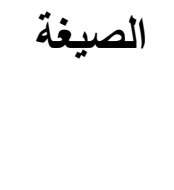 \\
\hline 48 مازوره & الطول \\
\hline 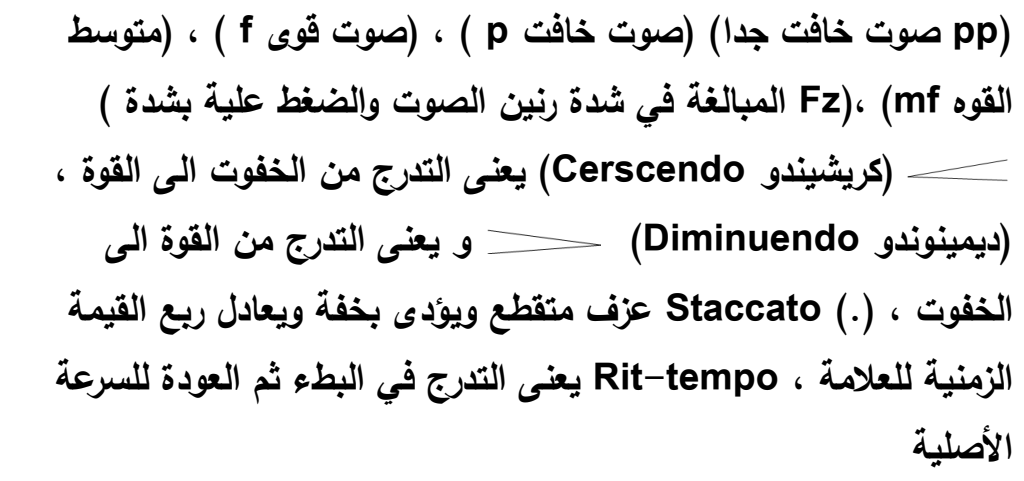 & مصطلحا \\
\hline أستخدم المؤلف البيدال فى حدود ضيقة & 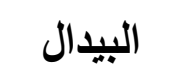 \\
\hline 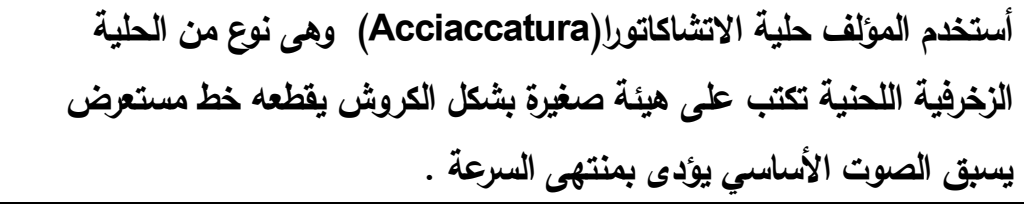 & 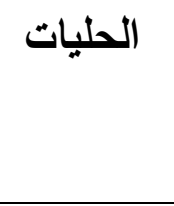 \\
\hline تصلح هذه المؤلفة للطالب المتميز & المستوي \\
\hline
\end{tabular}




\begin{tabular}{|c|c|}
\hline رقj Massigschell $\{$ Allegro moderatio J=c.92] & رقمئ \\
\hline صول / ك & 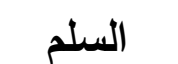 \\
\hline وتعنى سريع و نشيط الى حـ ما Massig schnell & السرعة \\
\hline $\begin{array}{l}3 \\
4\end{array}$ & 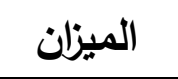 \\
\hline $\begin{array}{c}\text { A B A } \\
\mathrm{m} .1 \mathrm{~m} .17 \mathrm{~m} .49\end{array}$ & الصيغة \\
\hline - 64 مازورة & الطول \\
\hline 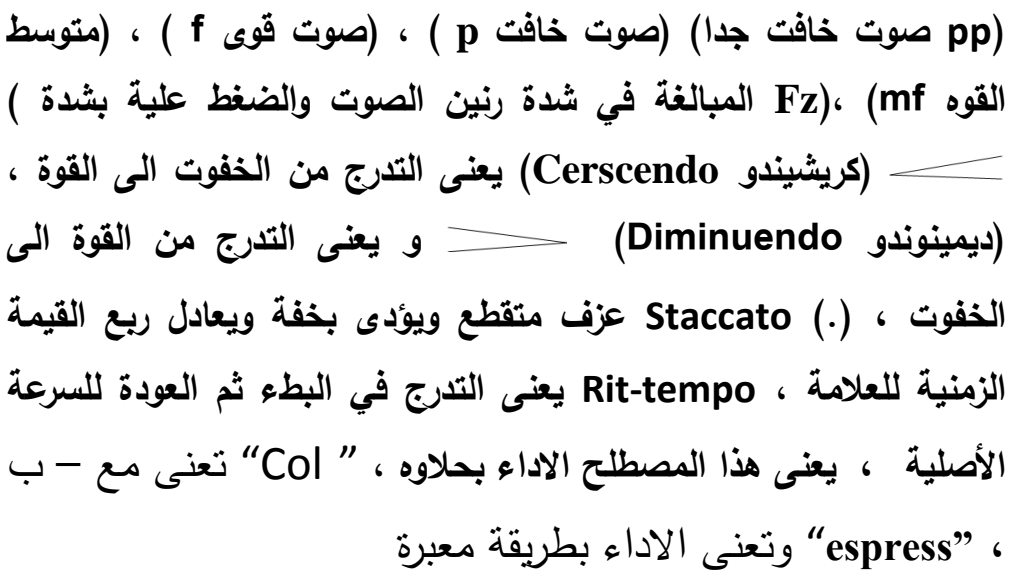 & مصطلحات \\
\hline لم يستخدم المؤلف أي نوع من الطليات & 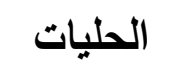 \\
\hline أستخدم المؤلف البيدال طوال المؤلفة لوجود مصطلح "Col" تعنى مع - & 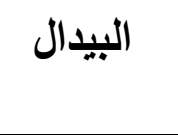 \\
\hline
\end{tabular}


مجلة البحوث فى مجالات التربية النوعية

\begin{tabular}{|l|l|}
\hline المستوي & التدريسي هذه المؤلفة للطالب المتميز \\
\hline
\end{tabular} 
مجلة البحوث في مجالات التربية النوعية

\title{
ملحق (2)
}

\section{استمارة استطلاع رأي الخبراء}

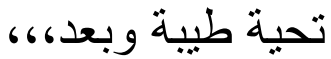

تقوم الباحثة بإجر اء دراسة بعنوان: الاستفادة من مجلد المقطوعات القصيرة

لثيودور كيرشنر لتحسين أداء الطالب على أله البيانو

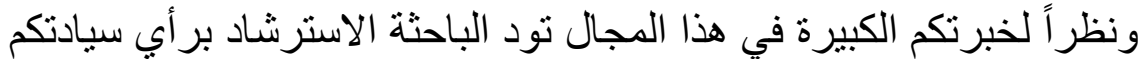

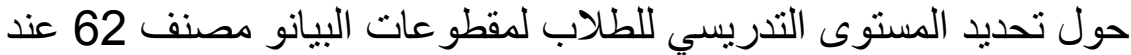

الرجاء أبداء الراي لما ترونه مناسبا

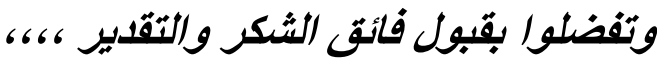

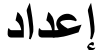 \\ أ.م.د/ منى عبد الرحيم عادلى إلى الرئ

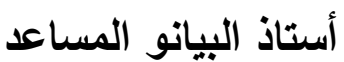 \\ كلية التربية النوعية جامعة جنوب الوادي اليانو المياعي
}

2021 
استمارة استطلاع رأى الخبراء لتحديد المستوى التدريسي لمقطوعات البيانو

$$
\text { عند كيرثنر }
$$

\begin{tabular}{|c|c|c|c|c|}
\hline وافق الى حد & لا أوافق & | أوافق & المستوى التدريسي & اسم العمل \\
\hline & & $\sqrt{ }$ & تصلح للطب المتوسط & | منمنمة رقم (1) \\
\hline & & $\sqrt{ }$ & تصلح للطالب فوق المتوسط & | منمنمة رقم 2 \\
\hline & $\sqrt{ }$ & & تصلح للطالب فوق المتوسط & |منمنمة رقم 3 \\
\hline & & $\sqrt{ }$ & تناسب الطالب المتميز & |منمنمة رقم4 \\
\hline & & $\sqrt{ }$ & تصلح للطالب فوق المتوسط & منمنمة رقم 5 \\
\hline & & $\sqrt{ }$ & تصلح للطالب المتوسط & [منمنمة رقم 6 \\
\hline$\sqrt{ }$ & & . & تصلح للطالب المتوسط & منمنمة رقم 7 \\
\hline$\sqrt{ }$ & & 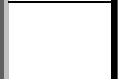 & تصلح للطالب فوق المتوسط & منمنمة رقم 9 \\
\hline & & $\sqrt{ }$ & تصلح للطالب المتميز & منمنمة رقم 10 \\
\hline & & $\sqrt{ }$ & تصلح للطالب المتميز & منمنمة رقم 11 \\
\hline & & $\sqrt{ }$ & تصلح للطالب المتميز & منمنمة رقم 12 \\
\hline$\sqrt{1}$ & & & تصلح للطالب المتوسط & |منمنمة رقم 13 \\
\hline & & $\sqrt{1}$ & تصلح للطالب المتميز & منمنمة رقم 14 \\
\hline$\sqrt{ }$ & & & تصلح للطالب فوق المتوسط & منمنمة رقم 15 \\
\hline
\end{tabular}


مجلة البحوث في مجالات التربية النوعية

ملحق (3)

استمارة استطلاع رأي الخبراء

السيد الأستاذ الدكتور|

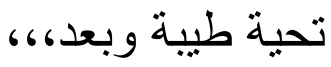

تقوم الباحثة بإجراء دراسة بعنوان: الاستفادة من مجلد المقطوعات القصيرة لثيودور كيرشنر لتحسين أداء الطالب على أله البيانو

ونظراً لخبرتكم الكبيرة في هذا المجال تود الباحثة الاسترشاد برأي سيادتكم فى

الصعوبات العزفية والتمارين المقترحة لعينه البحث وهم مقطوعة ( 5 ، 6 ، 7 ولئه

$(86$

الرجاء أبداء الراي لما نرونه مناسبا وتفضلوا بقبول فائق الشكر والتقلير ،6، كنائ

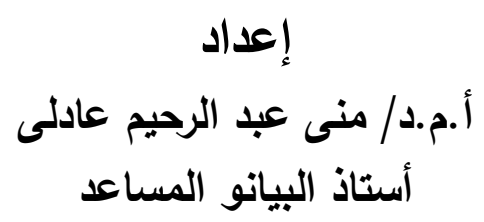

كلية التربية النوعية جامعة جنوب الوادى

2021 
جدول الصعويات العزفية والتمارين المقترحة لعينه البحث وهم مقطوعة ( 5 ، $(8 \cdot 7 \cdot 6$

\begin{tabular}{|c|c|c|c|c|}
\hline لا اوافق & او افق & الارشادات العزفية و التمارين & الصعوبات العزفية & r \\
\hline & & الاصنع الباحثة ضرورة الالتزام بترقيم & 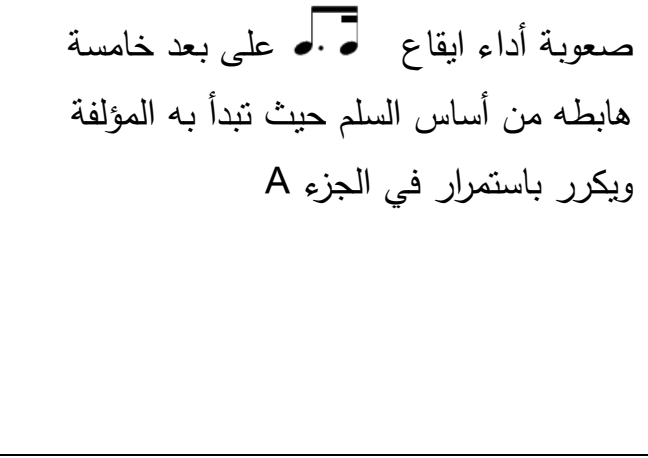 & مقطوعة \\
\hline & & 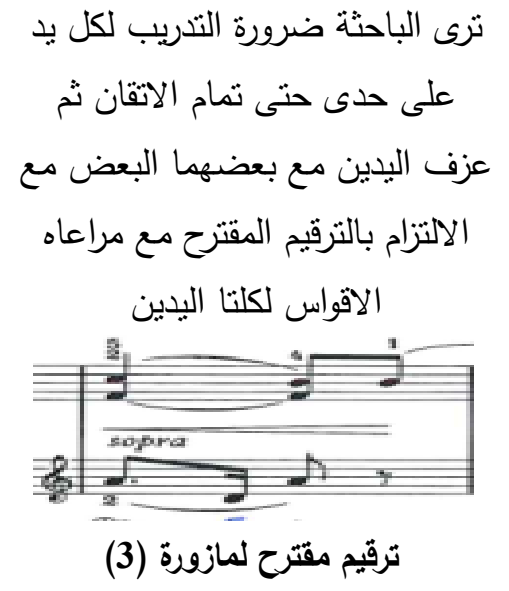 & صعوبة أداء النغمات اللحنية المتداخلة ما بين & \\
\hline & & لذا يجب مرة الاعباة عزف نغدة نغات الحلية & 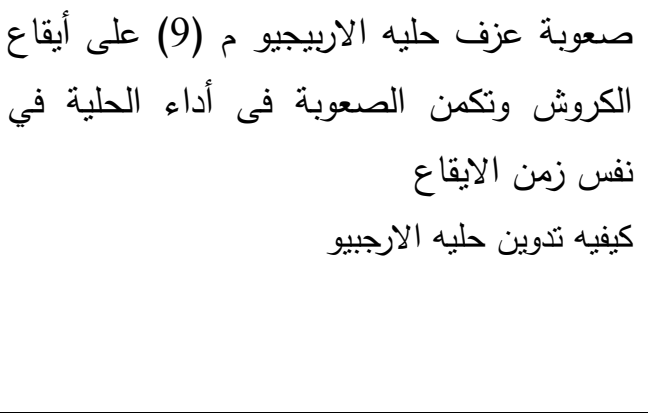 & \\
\hline
\end{tabular}




\begin{tabular}{|c|c|c|c|c|}
\hline & & 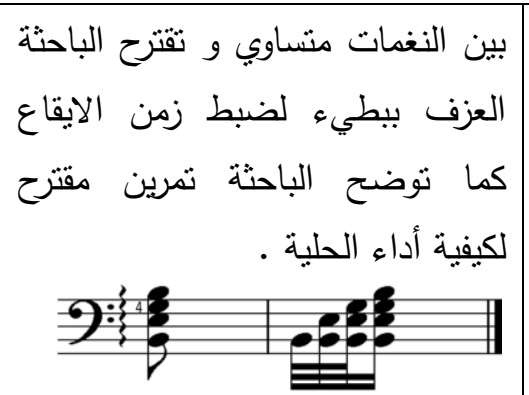 & تمرين لأداء حلية الاربيجيو & \\
\hline & & 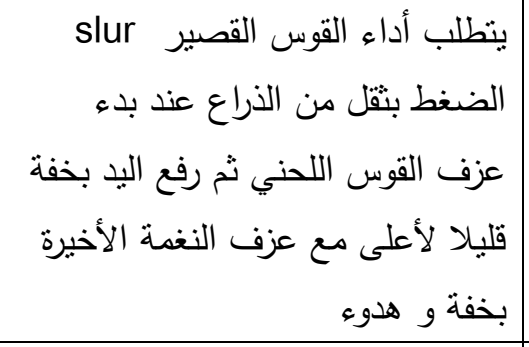 & 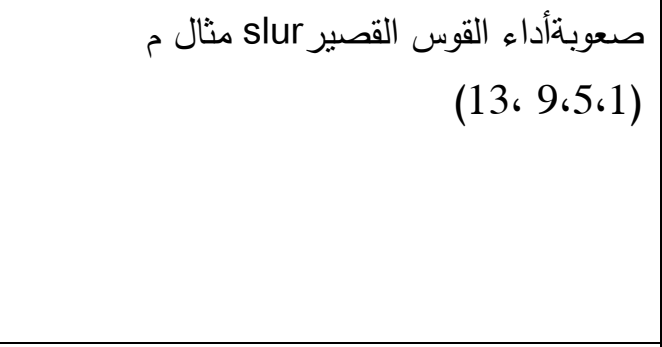 & مقطوعة \\
\hline & & 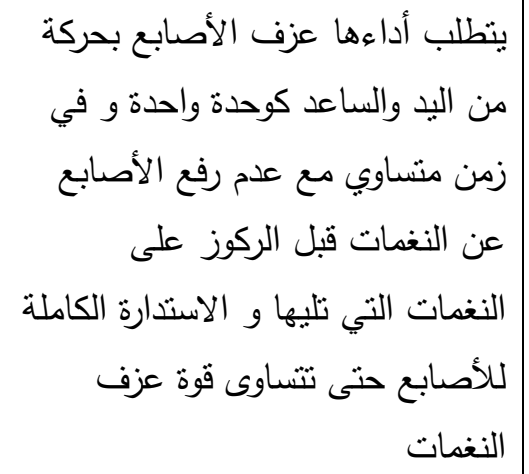 & staccato & \\
\hline & & 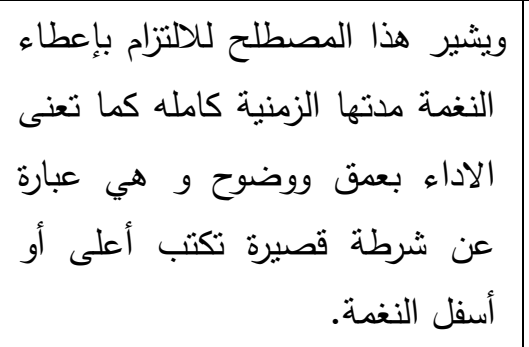 & 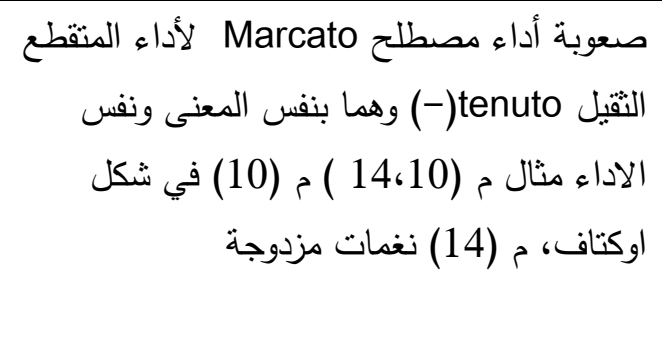 & \\
\hline & & 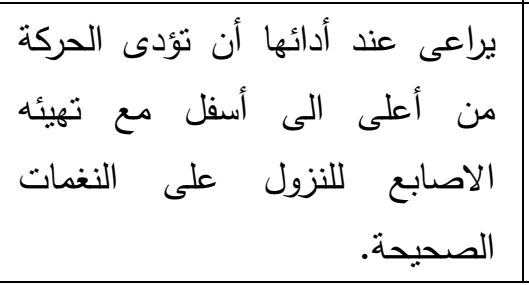 & 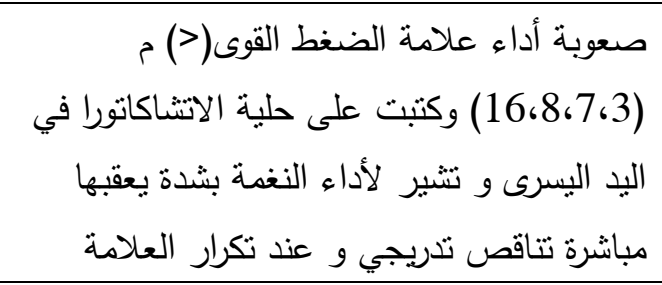 & \\
\hline
\end{tabular}


مجلة البحوث في مجالات التربية النوعية

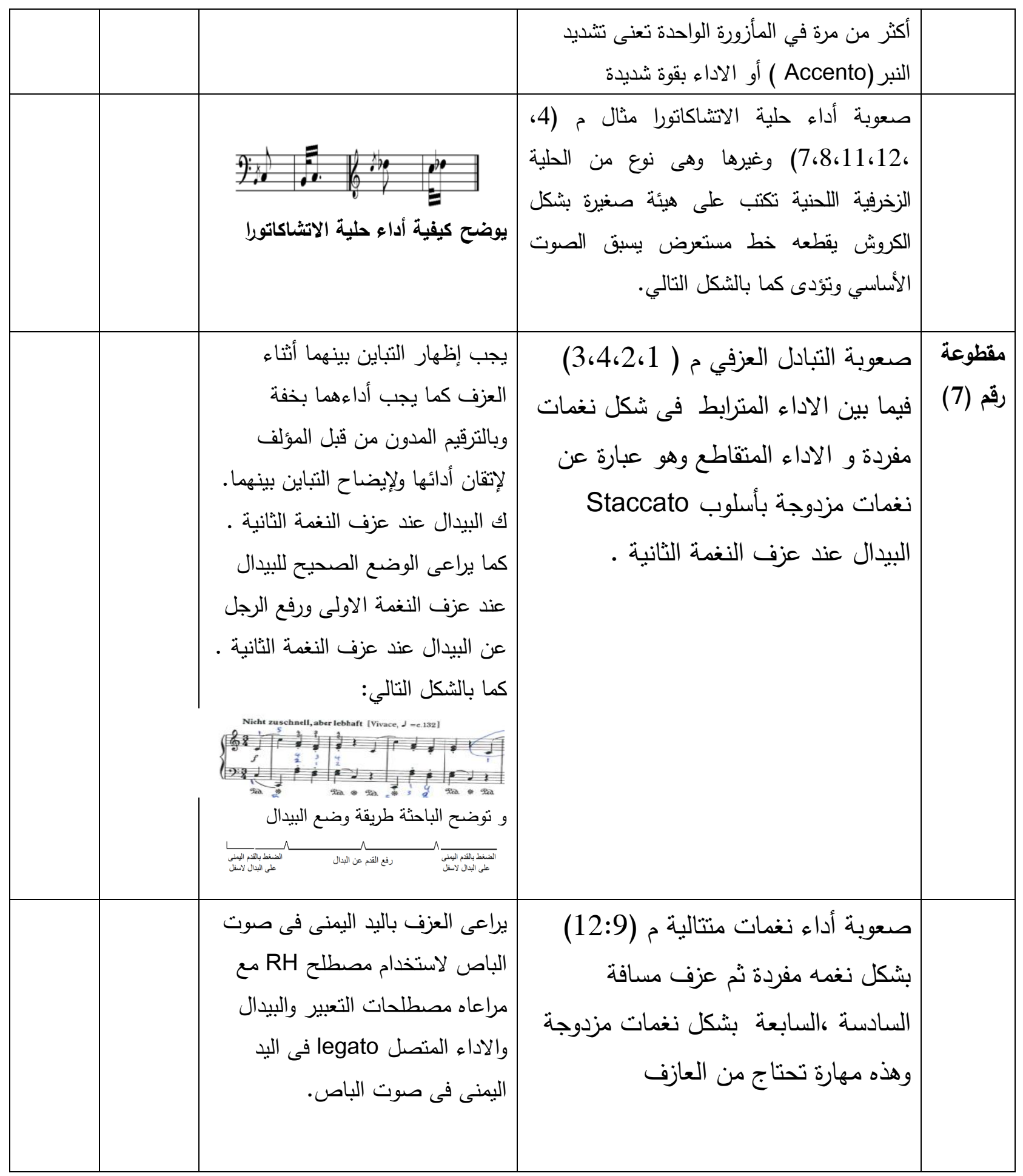


مجلة البحوث في مجالات التربية النوعية

\begin{tabular}{|c|c|c|c|c|}
\hline & & 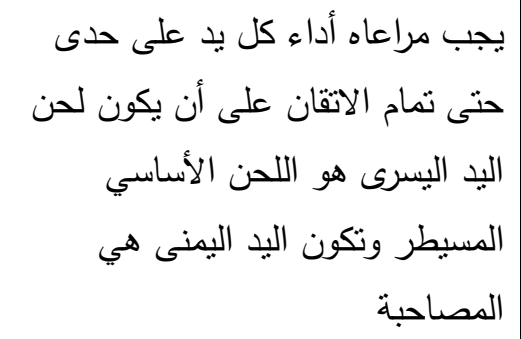 & و اليد اليمنى أداء اللحن المتبادل ما بين اليد اليسرى & مقطم (8) \\
\hline & & 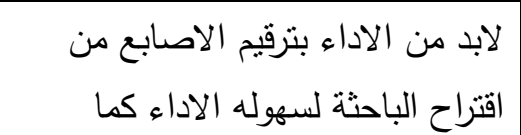 & صعوبة عزف الاقواس اللحنية بالثكل الصحيح & \\
\hline
\end{tabular}


مجلة البحوث في مجالات التربية النوعية

\section{ملحق (4)}

اسماء السادة المحكمين

\begin{tabular}{|c|c|c|}
\hline ل لوظيفة & 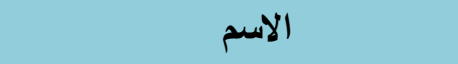 & \\
\hline استاذ البيانو -كلية التربية الموسيقية -جامعة & ا ا.د/ يونس بلر & 1 \\
\hline استاذ البيانو -كلية التربية الموسيقية - جامعة & ا.د/ شريف زين العابدين & 2 \\
\hline $\begin{array}{l}\text { استاذ البيانو -كلية التربية النوعية - جامعه } \\
\text { جنوب الوادي }\end{array}$ & 1.د/ أمل محمد طلعت اسماعيل & 3 \\
\hline استاذ المناهج وطرق التدريس -كلية التربية & ا.د/بلرية حسن على & 4 \\
\hline استاذ البيانو المساعد- كلية التربية النوعية- & ا.م.د/ ابتسام ربيع على & 5 \\
\hline جنتاذ البيانو المساعد- كلية التربية النوعية-جامعة الوادى & ا.م.د/ايمان عبد الفتاح & 6 \\
\hline استاذ البيانو المساعد-كلية التربية النوعية - جامعة جنوب الوادى & ا.م .د/ سماح خلف & 7 \\
\hline
\end{tabular}

